\title{
The Economics of Power Plant District and Process Heating in Richland, Washington
}

\author{
L. L. Fassbender \\ C. H. Bloomster
}

April 1981

Prepared for the U.S. Department of Energy under Contract DE-AC06-76RLO 1830

Pacific Northwest Laboratory Operated for the U.S. Department of Energy by Battelle Memorial Institute 
NOTICE

This report was prepared as an account of work sponsored by the United States Government, Neither the United States nor the Department of Energy, nor any of their employees, nor any of their contractors, subcontractors, or their employees, makes any warranty, express or implied, or assumes any legal liability or responsibility for the accuracy, completeness or usefulness of any information, apparatus, product or process disclosed, or represents that its use would not infringe privately owned rights.

The views, opinions and conclusions contained in this report are those of the contractor and do not necessarily represent those of the United States Government or the United States Department of Energy.

\author{
PACIFIC NORTHWEST LABORATORY \\ operated by \\ BATTELLE \\ for the \\ UNITED STATES DEPARTMENT OF ENERGY \\ Under Contract DE-AC06-76RLO 1830
}
Printed in the United States of America Available from
National Technical Information Service United States Department of Commerce 5285 Port Royal Road
Springfield, Virginia 22151

Price: Printed Copy $\mathbf{S}$ - $:$ Microfiche $\$ 3.00$

NTIS

-Pages Selling Price

$\begin{array}{lr}001-025 & \$ 4.00 \\ 026-050 & \$ 4.50 \\ 051-075 & \$ 5.25 \\ 076-100 & \$ 6.00 \\ 101-125 & \$ 6.50 \\ 126-150 & \$ 7.25 \\ 151-175 & \$ 8.00 \\ 176-200 & \$ 9.00 \\ 201-225 & \$ 9.25 \\ 226-250 & \$ 9.50 \\ 251-275 & \$ 10.75 \\ 276-300 & \$ 11.00\end{array}$




\section{7}

PNL -3719

UC-12

THE ECONOMICS OF POWER PLANT DISTRICT AND PROCESS

HEATING IN RICHLAND, WASHINGTON
L. L. Fassbender
C. H. Bloomster

Apri1 1981

Prepared for

the U.S. Department of Energy

under Contract DE-ACO6-76RLO 1830

Pacific Northwest Laboratory

Richland, Washington 99352 


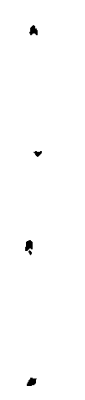




\section{TABLE OF CONTENTS}

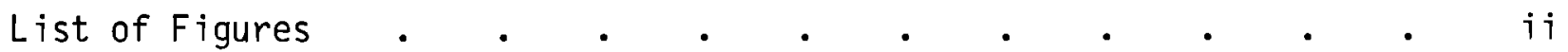

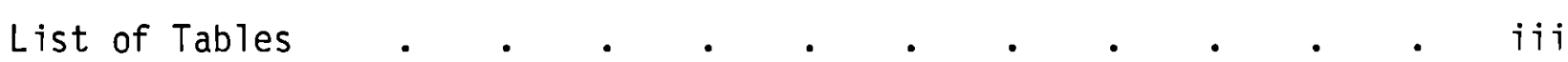

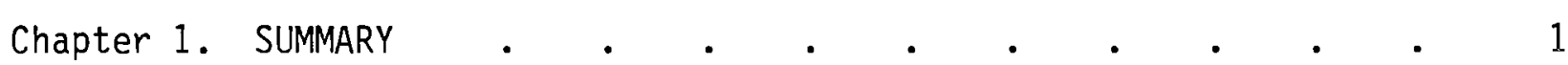

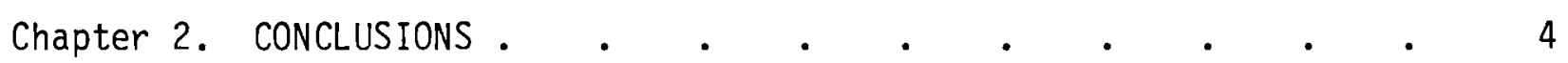

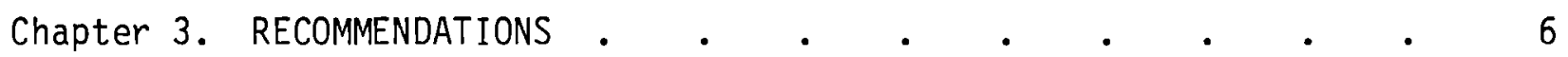

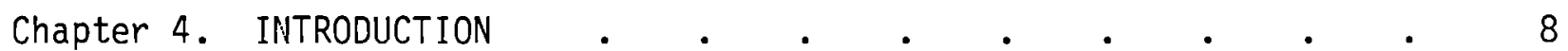

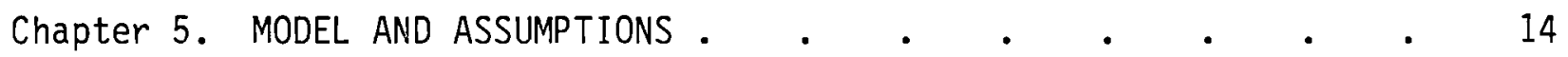

Chapter 6. DISTRICT HEATING COSTS FOR THE CITY OF RICHLAND. • • 19

Chapter 7. PROCESS HEATING COSTS FOR THE LAMB-WESTON

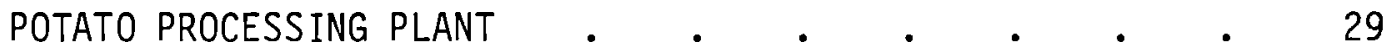

Chapter 8. DISTRICT HEATING COSTS FOR THE HORN RAPIDS

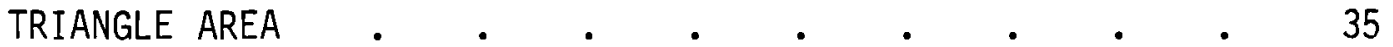

Chapter 9. PROCESS HEATING COSTS FOR THE 300 AREA • . • • • 40

Chapter 10. PROCESS HEATING COSTS FOR THE 3000 AREA • • • . 47

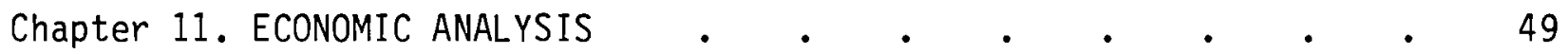

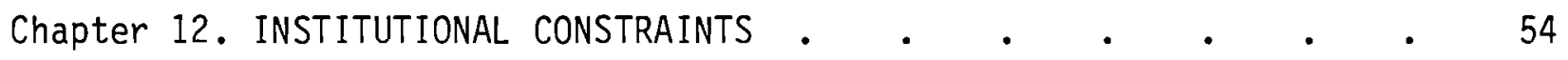

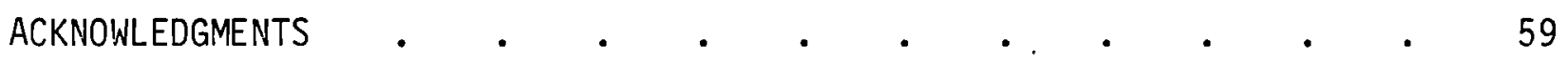

BIBLIOGRAPHY

DISTRIBUTION 


\section{LIST OF FIGURES}

6.1 Location of District Heating Demand in the City of Richland . 20

6.2 Simplified Block Flow Diagram for WNP-1 . . . . . . 22

6.3 Heat Exchanger at WNP-1 Boundary for District Heating
in the City of Richland. . . . . . . . . . 23

6.4 Layout of Heating Districts in Richland . . . . . . 26

7.1 Location of the Lamb-Weston Potato Processing Plant . • . 30

7.2 Heat Exchanger at WNP-1 Boundary for Process Heating at the Lamb-Weston Potato Processing Plant . . . . . 31

7.3 Flash Conditions at Potato Processing Plant . . . . . 33

8.1 Location of Horn Rapids Triangle Area . . . . . . 36

8.2 Heat Exchanger at WNP-1 Boundary for District Heating

9.1 Location of the 300 Area . . . . . . . . . 41

9.2 Heat Exchanger at WNP-1 Boundary for Process Heating

9.3 Flash Conditions at the 300 Area . . . . . . . 44

10.1 Location of the 3000 Area $\quad$. . . . . . . 48

11.1 Piping Network for Combined District
and Process Heating 


\section{$\underline{\text { LIST OF TABLES }}$}

1.1 Summary of District and Process Heating Applications . . . 1 .

5.1 Costs for Hot Water in PWR Turbine Cycle (WNP-1 or WNP-4) . . 16

6.1 Characteristics of Richland District Types . . . . . . 25 


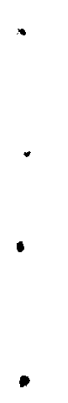




\section{RESULTS}

This report assesses the economic feasibility of utilizing hot water from the Washington Public Power Supply System's WNP-1 reactor to provide district heating for private residences and commercial areas in Richland, Washington. It also examines the economics of supplying hot water for two process heat demands in the vicinity. Eight combinations of district and process heating systems were analyzed (Table 1.1). All but. two of these applications appear to be economically feasible. Supplying process heat to only the Lamb-Weston plant is not economical because both the fluid demand and the $\Delta T$ utilized are too low. Supplying process heat to only the 300 area is not competitive with the cost of either oil or coal, the currently used fuels.

TABLE 1.1. Summary of District and Process Heating Applications

\begin{tabular}{|c|c|c|c|c|}
\hline Case & Application* & $\begin{array}{l}\text { Annual } \\
\text { Heat Demand, } \\
10^{6} \text { BTU/yr } \\
\end{array}$ & $\begin{array}{c}\text { Unit } \\
\text { Cost of Delivered } \\
\text { Heat, } \$ 110^{6} \text { BTU }\end{array}$ & Comments \\
\hline 1 & A & 907,640 & 15.92 & Feasible \\
\hline 2 & B & 208,700 & 19.13 & $\begin{array}{l}\text { Not } \\
\text { feasible }\end{array}$ \\
\hline 3 & C & 359,030 & 15.41 & Feasible \\
\hline 4 & D & 504,990 & 10.87 & $\begin{array}{l}\text { Not } \\
\text { feasible }\end{array}$ \\
\hline 5 & $D+E$ & 573,570 & 9.94 & $\begin{array}{l}\text { Probably } \\
\text { feasible }\end{array}$ \\
\hline 6 & $D+E+A$ & $1,481,210$ & 8.46 & Feasible \\
\hline 7 & $B+C$ & 567,730 & 11.03 & Feasible \\
\hline 8 & $A+B+C+D+E$ & $2,048,940$ & 9.17 & Feasible \\
\hline \multicolumn{5}{|c|}{$\begin{array}{l}* \bar{A}=\text { district heating in Richland (north of the Yakima River) } \\
B=\text { process heating at the Lamb-Weston potato processing plant } \\
C=\text { district heating in the Horn Rapids Triangle area } \\
D=\text { process and space heating in the } 300 \text { area } \\
E=\text { space heating in the } 3000 \text { area }\end{array}$} \\
\hline
\end{tabular}


District Heating in Richland

Space heating and supply of sanitary hot water for the City of Richland through a district heating system represents a major potential use for the hot water from the WNP-1 reactor (Case 1). About $8.8 \times 10^{11}$ BTU/year of the WNP1 heat could be utilized in district heating. Peak demand of the district heating system would be $3.25 \times 10^{8}$ BTU/hour. The cost of district heating in Richland ( $\$ 15.92 /$ million BTU) is $15 \%$ lower than the marginal cost of electric resistance heating ( $\$ 18.73 / \mathrm{million}$ BTU), based on WPPSS estimates of the future cost of power from WNP-1. The cost could be lowered dramatically by using the hot water to satisfy the process and space heat demands of the 300 and 3000 areas north of Richland, and then cascading the water to the district heating system (Case 6). Case 6 is the best case; the cost is only $6 \%$ higher than the projected average cost of electric resistance heating, and less than half the marginal cost.

Process Heating at the Lamb-Weston Potato Processing Plant

We also simulated a hot water transmission pipe from the WNP-1 reactor to the Lamb-Weston potato processing plant near the Richland Airport (Case 2). The hot water is flashed at the plant to provide 140 PSIG process steam, for which the peak demand is $28.68 \times 10^{6}$ BTU/hour. Supplying process heat to only the Lamb-Weston plant is not economical because both the fluid demand and the $\Delta T$ utilized are too low.

In Case 7 , the reject water from the flash is distributed to the planned residential development in the Horn Rapids Triangle area for space heating. Such a cascading scheme would increase the utilization of energy, thereby reducing the unit cost of heat to the consumers. Case 7 appears to be economically feasible; its cost is $42 \%$ lower than the cost of Case 2 . 
Combined District and Process Heating Simulation

We also simulated district heating for the planned residential development in the Horn Rapids Triangle area (Case 3), process and space heating in the 300 area only (Case 4), and space heating in the 3000 area of north Richland combined with the 300 area (Case 5). Case 3 appears feasible since the cost is $18 \%$ lower than the marginal cost of electric resistance heating. Case 4 is not economically feasible, since the cost is much higher than the cost of either oil or coal, the fuels currently used to fire the 300 area boilers. Case 5 is probably feasible, depending upon how the cost is allocated between the 300 and 3000 areas. The competition in the 3000 area is currently from several sources, including electricity and natural gas.

The impact of combining process heating at the Lamb-Weston potato processing plant with district heating in the Horn Rapids Triangle, plus process and space heating in the 300 and 3000 areas with district heating in Richland was significant. The combination of these district and process heating applications (Case 8 ) resulted in an overall cost of heat of $\$ 9.17 / \mathrm{million}$ BTU. This is only $15 \%$ more than the expected average cost of electric heating in Richland by 1985 . HOT WATER SUPPLY

For this report, the energy is assumed to be sold by the Washington Public Power Supply System (WPPSS) to the City of Richland at the boundary of the WNP1 plant site. WPPSS identified streams of varying temperatures and quantities that would be available from seven different points in the boiler feedwater condensate units. For all applications, the highest-temperature $\left(431^{\circ} \mathrm{F}\right)$ boiler feedwater condensate stream was the most cost-effective energy source. This hot water was priced by WPPSS at $\$ 5.72 / 10^{6}$ BTU. 
Chapter 2. CONCLUSIONS

If financing and incentives can be arranged to achieve nearly $100 \%$ participation, then district heating in Richland is competitive with the marginal cost of electric resistance heating, and under conditions of widespread application, combined district and process heating would also be competitive with $0 i 1$ and gas heat. Therefore, the potential use of hot water from WNP-1 or the other reactors under construction deserves serious consideration.

The district heating system can be organized in several ways to increase the load factor and reduce the unit cost of energy. Such possibilities as population growth, influx of new process heat users, district cooling during the summer, and energy storage should be investigated. A11 factors that increase total energy demand and increase the system load factor would be effective in lowering the cost of district heating.

There are a number of obstacles to district heating in Richland. These include: (1) the need to organize a large and concentrated market, (2) the need to obtain pricing incentives that offset the difference between the average and marginal cost of conventional heating, and (3) the need for a financing method that defrays or spreads retrofit costs for existing residences. In addition, permission of the WNP-1 plant participants and bondholders must be obtained. Nevertheless, if district heating is perceived to be cheaper and better than conventional heating, these obstacles would be readily overcome.

The marginal cost of heating is the appropriate criterion for economic comparison. Since the cost of the district/process heating system is less than the marginal cost of electricity from WNP-1 and the projected cost of $0 i 1$ and gas heat, it represents a net benefit to society, and should therefore be 
preferable to conventional heating. The users of the district heating system, however, should not be penalized for this more-efficient use of energy. The pricing of district heat should be based on the average cost of conventional heat to these users. That is, both the costs and the benefits (electricity saved) should be spread throughout the region via an equitable pricing mechan ism. 
Chapter 3. RECOMMENDATIONS

\section{DETAILED FEASIBILITY STUDY}

Due to the favorable economics of this preliminary analysis of several district and process heating applications, we recommend a much-more-extensive, detailed feasibility study. This study would include the commercial districts in Richland, Kadlec Hospital, all of the DOE contractors' offices along George Washington Way, additional portions of the Hanford Site, and potential new industries in the Horn Rapids Triangle area. Finally, the economics of district cooling and energy storage should be investigated. The detailed study should develop a preliminary system design and obtain detailed engineering cost estimates for the major system components. We feel that since our preliminary study indicates competitiveness with conventional heating, an excellent opportunity exists here in Richland to demonstrate the commercial viability of cogeneration on a large scale.

DEMONSTRATION PROGRAM

Contingent upon favorable results of the detailed feasibility study, we would recommend a large-scale demonstration program. Conditions exist in Richland for a successful demonstration of nuclear cogeneration. These include a potential large supply of hot water from nuclear reactors and large heating and cooling demands of research laboratories, offices, and private residences. The City of Richland's plans to develop the Horn Rapids Triangle present a unique opportunity for a district heating system to be installed at the same time that other utilities are being installed. Such a system could also provide process heat for Hanford, for potential new industries in the Horn Rapids Triangle, and for existing industries.

A demonstration of district heating in Richland could have an impact far beyond the local community. A variety of general problems would exist for any 
community that attempts to establish a district heating system. The general problems seem to be:

- Absence of local experience in building and operating district heating systems.

- Unwillingness of private companies to engage in operating a utility, subject to undefined regulations.

- Extensive retrofitting of building HVAC systems to use hot water.

- Resistance to change, both in the use of new materials and technologies, and in establishing new patterns of supply and consumption.

Since most of these problems are attitudinal and institutional, a successful demonstration program could provide the impetus for the establishment of district heating programs throughout the country.

We feel that Richland is a prime site for such a demonstration program. The WPPSS reactors are relatively close to town, the public is extremely pronuclear, and the economics are favorable. We recommend serious consideration of this opportunity by DOE, WPPSS, and the City of Richland, since the cooperation of all parties would be required to reach some sort of cost-sharing arrangement that might speed up a demonstration program. 
Chapter 4. INTRODUCTION

The purpose of this report is to assess the economic feasibility of utilizing hot water from nuclear reactors to provide district heating for private residences in Richland, Washington, and space and process heating for nearby offices, part of the Hanford Reservation, and the Lamb-Weston potato processing plant. Specifically, the report will establish the practicality of usina hot water from the Washington Public Power Supply System's WNP-1 reactor, which is currently under construction on the Hanford Reservation, iust north of the City of Richland. The conclusions are based on data supplied by the Washington Public Power Supply System (WPPSS) regarding the availability of hot water and its pricing structure, and on data supplied by the City of Richland regarding housing densities and layouts of the various districts to be served. This chapter describes world-wide experience with district heating systems and the advantages of using these systems.

ADVANTAGES OF DISTRICT HEATING

As conventional energy prices continue to escalate and as the availability of foreign oil supplies becomes more uncertain, we must re-evaluate our energy options. District heating is one method of reducing total energy consumption and conserving scarce fossil fuels. These advantages accrue because district heating systems use low-quality energy sources to meet space and process heating demands which are currently being satisfied by high-quality energy sources. Nearly 50 percent of the energy consumed for heating in the United States is for applications requiring temperatures less than $100^{\circ} \mathrm{C}\left(212^{\circ} \mathrm{F}\right)$. It is estimated that half of these demands could be economically satisfied by the use of district heating. This would result in a savings of at least 750,000 barre1s of 011 per day ${ }^{(4.1)}$. 
In a conventional thermal power plant, electricity is generated at an efficiency of 30-35 percent. The other 65-70 percent of the fuel energy is rejected in the condenser as low-temperature water, which is not effectively utilized. However, it is possible to modify the turbine cycle and extract some of the thermal energy from the electric generation process at temperatures high enough to be useful.

A district heating system can effectively use power plant hot water for space heating and process heating in the surrounding community. This is an old concept that is prevalent in Europe. A power plant that produces both heat and electric power is called a cogeneration plant. For each BTU of heat extracted, there is a reduction in the amount of electricity generated, but the combination of heat and electricity production results in significant fuel savings. In fact, a cogeneration plant can achieve an overall efficiency of 6070 percent, which is double that of a conventional thermal power plant ${ }^{(4.2)}$.

The 60-70 percent efficiency quoted above represents a plant that is designed from the beginning for cogeneration. Retrofitting WNP-1 will not achieve such a high efficiency, although it will increase the efficiency over that of electricity generation alone. For this study we are not using waste heat from the condenser, but energy from the steam cycle itself. Withdrawal of energy from the WNP-1 steam cycle would directly affect the electrical output of the plant.

WPPSS is obliged to consider requests for use of waste heat from their WNP2 plant. They are required to provide about 4,000 GPM of warm water from WNP-2 if there is a reasonable user identified. This water could be extracted either just downstream of the condenser before it enters the cooling tower (hot leg), or from the blowdown line downstream of the cooling tower (cold leg). The blowdown temperature would vary from $57-75^{\circ} \mathrm{F}$. The hot leg water would be about $29^{\circ} \mathrm{F}$ warmer. 
Although WPPSS is not obliged to consider requests for use of waste heat from WNP-1 or WNP-4, they probably would do so. About 4,000 GPM would also be available from each plant. Blowdown temperatures would vary from $68-87^{\circ} \mathrm{F}$. Hot leg water would be about $28^{\circ} \mathrm{F}$ warmer. WPPSS is not under any obligation to consider requests for use of heat from the steam cycle itself, which is what this study is concerned with.

WORLD-WIDE EXPERIENCE WITH DISTRICT HEATING

In district heating systems a network of insulated pipes distributes heat, using either hot water or steam, to commercial and residential customers from a central distribution point. European systems use hot water almost exclusively. Existing U.S. systems primarily use steam. In single-pipe, oncethrough distribution systems, fluid disposal is through a sewer system. In twopipe systems, the fluid is recirculated, conserving the fluid and residual heat. Two-pipe systems cost approximately $20 \%$ more than single-pipe systems.

There are currently 116 commercial suppliers of district heating energy in the United States ${ }^{(4.3)}$, plus numerous small district heating systems for universities, military bases, and shopping centers. Most of these systems provide steam to only large demands located near steam-generating plants.

There is considerable international experience with district heating systems. For example, District Heating reports that:

"...more than 50\% of domestic heat demand in the Soviet Union is already supplied by heat power stations. In Denmark, more than $30 \%$ of the homes are now on district heating and by 1980 , service will have reached over 50\%; in Sweden around $70 \%$ of space heating needs will be supplied by district heating in 1980. Also between 20 and $60 \%$ of the inhabitants of Finnish towns will be supplied by district heating."(4.4)

Most of these systems use hot water in the temperature range of $70^{\circ} \mathrm{C}$ to $150^{\circ} \mathrm{C}\left(158^{\circ} \mathrm{F}\right.$ to $\left.302^{\circ} \mathrm{F}\right)$. 
Major factors accounting for more widespread use of district heating in Europe include the following:

- Relatively more expensive energy;

- More centralized government control of utilities; and

- Government financing of the district heating systems.

Some district heating systems in Iceland serve small, relatively disperse heat loads. For example, in Akureyri $90^{\circ} \mathrm{C}\left(194^{\circ} \mathrm{F}\right)$ water is transmitted 12 $\mathrm{km}$ (7.5 miles) to serve 11,000 people in an area with a density of about 2400 persons per square $\mathrm{km}$ (6000 persons per square mile). This is about the same density as in suburban areas of the United States.

On the Reykjanes Peninsula, Iceland, 7 towns with a total population of 15,000 people and an average density of about 2400 persons per square km $(6000$ persons per square mile) are all served by a single district heating system supplying $88^{\circ} \mathrm{C}\left(190^{\circ} \mathrm{F}\right)$ water. Transmission pipes $11 \mathrm{~km}$ ( 7 miles) long are required to connect some of the towns $(4.5)$.

France has built a district heating system which circulates $55^{\circ} \mathrm{C}$ $\left(131^{\circ} \mathrm{F}\right)$ water to some buildings and uses a heat pump to boost the water temperature to $90^{\circ} \mathrm{C}\left(194^{\circ} \mathrm{F}\right)$ for other buildings ${ }^{(4.6)}$. The Chicago South Loop New Town project plan endorses the use of modular heat pumps for the new town. This system would involve the circulation of $16^{\circ} \mathrm{C}\left(61^{\circ} \mathrm{F}\right)$ water with heat pumps to individual buildings, providing heating or cooling as required. Estimates are that capital costs would be about $6 \%$ less and operating costs would be about $56 \%$ less than those for a conventional system ${ }^{(4.5)}$.

Sweden was a pioneer in the use of nuclear power for district heating purposes. Farsta, a suburb of Stockholm, was heated by the Agesta nuclear reactor for 16 years, but the system was scrapped because of rock-bottom oil prices $^{(4.7)}$. 
By 1990 it is forecast that $60 \%$ of the district heating in Sweden will be provided by nuclear power. Plans for Stockholm envisage a 2000 MWe nuclear power station located southeast of the City of Haninge. The system would supply hot water through a distribution network extending more than 60 kilometers ${ }^{(4.4)}$.

Preparations are currently being made in Germany to develop a nuclear district heating network which will encompass every city with a population of 40,000 or more. It is estimated that $94 \%$ of the space heating and sanitary hot water heating demand in West Germany can be met by this system (4.4).

The U.S.S.R . is the largest user of district heating in the world and is continuing to expand its capacity. Cities with populations of over 100,000 are generally served by district heating. The U.S.S.R. is also the only country currently using heat derived from nuclear reactors. Two nuclear power plants in the U.S.S.R. are now in operation supplying district heating and domestic hot water heating to customers. The operational experience of these two plants has proved the technical and economic feasibility of nuclear district heating (4.8).

Many different types of district heating systems are in existence. Each system has specific characteristics which make its use relatively more advantageous in some situations. In the United States there has been considerable resistance to the use of hot water distribution systems, particularly where water in the $70^{\circ} \mathrm{C}$ to $150^{\circ} \mathrm{C}\left(158^{\circ} \mathrm{F}\right.$ to $\left.302^{\circ} \mathrm{F}\right)$ range is used. Historically, this resistance was caused by the availability of inexpensive oil and gas. However, as the prices of $0 i 1$ and gas increase, hot water district heating systems become increasingly desirable by offering the potential of significant energy savings. 


\section{Chapter 4. FOOTNOTES}

4.1 McDonald, C. L. An Evaluation of the Potential for District Heating in the United States (BNWL-SA-6259). Richland, Washington: Pacific Northwest Laboratory, 1977.

4.2 0liker, I. Cogeneration District Heating Applications. New York, New York: The American Society of Mechanical Engineers, December 1978.

4.3 "District Energy Suppliers in the United States and Canada". District Heating 62(3) (January-February-March 1977).

4.4 Winkens, Hans-Peter. "Germany Looks Toward Nuclear District Heating". District Heating 61(2) (October-November-December 1975): 22-26.

4.5 Sudurnes Hot Water System Primary Project. Reykjavik, Iceland: Fjarhitan, Ltd., March 1975.

4.6 La Geothermie Chauffage de Logements. Paris, France: Electricite de France, 1976.

4.7 Diamant, R. M. E. "District Heating with Combined Heat and Power Generation". District Heating 64(1) (July-August-September 1978): 30-40.

4.8 Beresovski, T., Spiewak, I., and 0liker, I. "Urban District Heating Using Nuclear Heat - A Survey". Atomic Energy Review (1979). 


\section{Chapter 5. MODEL AND ASSUMPTIONS}

This chapter describes the computer model used to calculate district heating costs and presents the assumptions upon which the costs are based. DESCRIPTION OF GEOCITY COMPUTER MODEL

The basis for the district heating costs is the unit cost of energy which will recover all the costs of production -- capital investment, operating expenses, taxes, and the specified rates of return on capital. My focus is on the economics of substituting district heating, based on production costs, for electric resistance heating.

The calculation of the unit cost of energy is based on life-cycle costing and discounted-cash-flow analysis. The GEOCITY model ${ }^{(5.1)}$ is used for these calculations. The unit cost of energy is derived from the following expression:

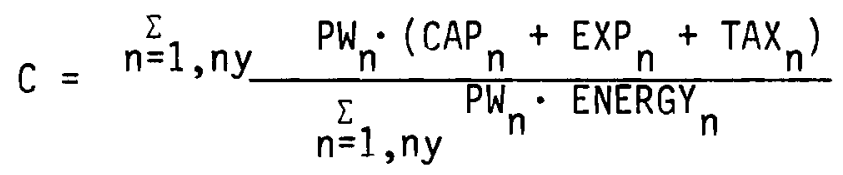

where: $\quad C=$ unit cost of energy, $\$ / 10^{6}$ BTU

$$
\begin{aligned}
\text { ny } & =\text { useful life, years } \\
\text { CAP } & =\text { capital costs, } \$ \text { in year } n \\
\text { EXP } & =\text { annual operating expenses, } \$ \text { /year } \\
\text { TAX } & =\text { annual taxes, } \$ / \text { year } \\
\text { PW } & =\text { present worth factor } \\
\text { ENERGY } & =\text { annual energy production, } 10^{6} \text { BTU/year } \\
n & =\text { year }
\end{aligned}
$$


GEOCITY is a computer simulation model developed to study the economics of district heating using geothermal energy. For this report, modifications were made to the model to simulate power plant district heating. GEOCITY calculates the cost of district heating based on climate, population, energy source characteristics, and financing conditions. The principal input variables are minimum temperature, heating degree days, population size and density, energy source temperature and distance from load center, and the interest rate. From this input data the model designs the transmission and district heating systems. From this design, GEOCITY calculates the capital and operating costs for the entire system.

GEOCITY can simulate nearly any financial and tax structure through varying the rates of return on equity and debt, the debt-equity ratios, and tax rates. Both private enterprise and municipal utility systems can be simulated.

GEOCITY calculates the cost of energy based on the principle that the present worth of the revenues will be equal to the present worth of the expenses, including investment return, over the economic life of the distribution system. The present worth factor is determined by the capital structure and rates of return on invested capital for the organization. The program incurs debt and equity at the specified ratio when expenses exceed revenues, and repays debt and equity in the same ratio when revenues exceed expenses. At the end of the project, debt and equity are exactly repaid and the project exactly earns the specified rate of return.

GEOCITY uses heat demand data and climatic data to determine the hot water requirements for each building. Working down the piping network, water requirements are used as the basis for selecting the economic pipe size for each segment of the network. Material requirements, heat losses, and pressure drops are determined for each segment of the piping network. Construction costs, material costs, operating costs, and costs for pumps, meters, and 
control equipment are derived based on the distribution system design. ASSUMPTIONS USED IN THE ANALYSES

For this report, the energy is assumed to be sold by WPPSS to the City of Richland at the boundary of the WNP-1 plant site. Energy from the WNP-4 reactor would also be hypothetically available, but our analysis will focus on WNP-1 only. Costs of various grades of hot water from the WNP-1 or WNP-4 secondary cycle would vary. Table 5.1 gives a range of grades of hot water and cost to WPPSS of diverting the water from seven different points in the boiler feedwater condensate units.

TABLE 5.1. Costs for Hot Water in PWR Turbine Cycle (WNP-1 or WNP-4) (a)

\begin{tabular}{|c|c|c|c|c|c|}
\hline \multirow[b]{2}{*}{ Hot Water (b) } & \multicolumn{5}{|c|}{$\operatorname{cost}(c)$} \\
\hline & Temperature & Enthalpy & PSI & WNP-1 & WNP -4 \\
\hline$(1 b / h r)$ & $\left({ }^{0} \mathrm{~F}\right)$ & (BTU/1b) & & $--(m i$ & (1b) -- \\
\hline $2,258,000$ & 126 & 94 & 3 & 0.44 & 0.48 \\
\hline $1,594,000$ & 171 & 139 & 6 & 0.69 & 0.77 \\
\hline $1,089,000$ & 217 & 185 & 16 & 0.96 & 1.05 \\
\hline 563,000 & 265 & 234 & 38 & 1.23 & 1.36 \\
\hline $5,424,000$ & 354 & 326 & 140 & 1.77 & 1.96 \\
\hline $3,438,000$ & 375 & 348 & 185 & 1.89 & 2.09 \\
\hline $2,393,000$ & 431 & 409 & 350 & 2.25 & 2.47 \\
\hline
\end{tabular}

Costs are based on the cost to bring the enthalpy of the make-up water $\left(50^{\circ} \mathrm{F}\right.$, 1 At. $=18.1$ BTU/Ib) to the enthalpy of water used. WNP-1 costs are based on

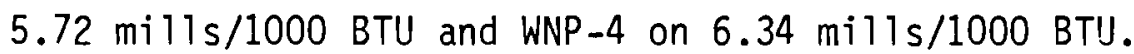

\footnotetext{
(a) Letter from Mr. Duane L. Renberger (Assistant Director, Technology, WPPSS), to Mr. Harold Harty (Battelle, Pacific Northwest Laboratory) dated August 8, 1980.

(b) Quantities are on an either/or basis rather than both/and.

(c) Does not include capital cost of tie-in.
} 
The costs in Table 5.1 are given in units of mills per pound of hot water taken from the plant site. However, this report assumes that the heat is transferred to a fresh* water source in a heat exchanger at the plant boundary. The City of Richland will purchase BTUs from WPPSS and transport this energy to the consumers via a fresh water pipeline. The water inside the WNP-1 secondary loop will remain within the plant boundary. Therefore, it is assumed that the purchased thermal energy will cost $5.72 \mathrm{mills} / 1000$ BTU as stated at the bottom of Table 5.1. This price is equivalent to $\$ 5.72 / 10^{6}$ BTU.

The City of Richland is an experienced operator of municipal utility services, including water and electricity. It is assumed that the City of Richland would construct and operate the hot water transmission pipe and the distribution system within the City. Financing for the project is assumed to be provided by the sale of municipal bonds at an interest rate of 8 percent. A11 cost estimates are in January 1980 dollars.

In addition to the cost of purchased thermal energy and the capital costs of the transmission and distribution piping systems, the cost of district heating must include the capital costs of building retrofit. We have assumed a retrofit cost of $\$ 1,000$ per dwelling unit for this report. Retrofit costs should be only about $\$ 500$ per house for houses that currently have hot-water or forced-air heating systems. For houses that require major modifications of existing heating systems, retrofit costs could be as high as $\$ 2,000$ per

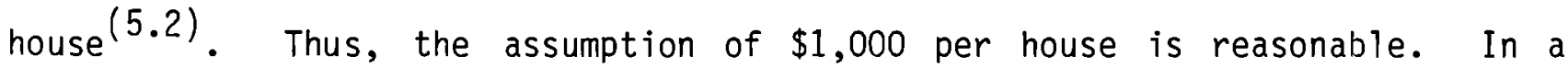
more detailed analysis, a comprehensive survey of existing heating systems could be undertaken to determine retrofit costs more accurately.

\footnotetext{
*In district heating parlance, the term "fresh" refers to an additional stream of water, different from the hot water inside the power plant.
} 


\section{Chapter 5. FOOTNOTES}

5.1 McDonald, C. L., Bloomster, C. H., and Schulte, S. C. GEOCITY: A Computer Code for Calculating Costs of District Heating Using Geothermal Resources (BNWL-2208). Richland, Washington: Pacific Northwest Laboratory, 1977.

5.2 Bloomster, C. H., Garrett-Price, B. A., and Fassbender, L. L., Residential Heating Costs - A Comparison of Geothermal, Solar, and Conventiona 7 Resources (PNL-3200). Richland, Washington: Pacific Northwest Laboratory, 1980. 
Chapter 6. DISTRICT HEATING COSTS FOR THE CITY OF RICHLAND

SUMMARY

We determined the cost of residential space heating in Richland using hot water from the WNP-1 reactor. Figure 6.1 shows the location of WNP-1 on the Hanford Site, about 8 miles north of the City of Richland. The portion of the city that was included in this district heating simulation is shown in red. This portion is bounded on the north by the DOE contractors' offices, on the west and south by the Bypass Highway, and on the east by the Columbia River. We did not include any of the houses in the Meadow Springs, Canyon Terrace, or Hills West housing developments south of the Yakima River, although they are part of the City of Richland.

The cost of district heating in Richland was $\$ 15.92 / 10^{6}$ BTU. The cost of purchased thermal energy from WPPSS accounts for $40 \%$ of the total cost. The costs of the initial investment in the transmission pipe and the distribution system, interim capital replacements, and operating expenses account for $60 \%$ of the total cost. About $8.8 \times 10^{11}$ BTU/year of the WNP-1 heat could be utilized in district heating in Richland. Peak demand of the district heating system would be $3.25 \times 10^{8} \mathrm{BTU} /$ hour. The cost of district heating in Richland is $15 \%$ lower than the marginal cost of electric resistance heating, based on WPPSS estimates of the future cost of power from WNP-1.

THE WNP -1 REACTOR

The WNP-1 reactor is a pressurized water reactor (PWR). The heat of a PWR is transferred from the reactor via three loops. The primary loop is water heated in the reactor and pumped to the steam generator. The secondary loop cycles heat from the steam generator, in the form of steam, through the turbine to the condenser, where it is condensed back to a liquid state. The tertiary loop carries the heat from the condenser to a cooling tower where the heat is 


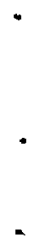




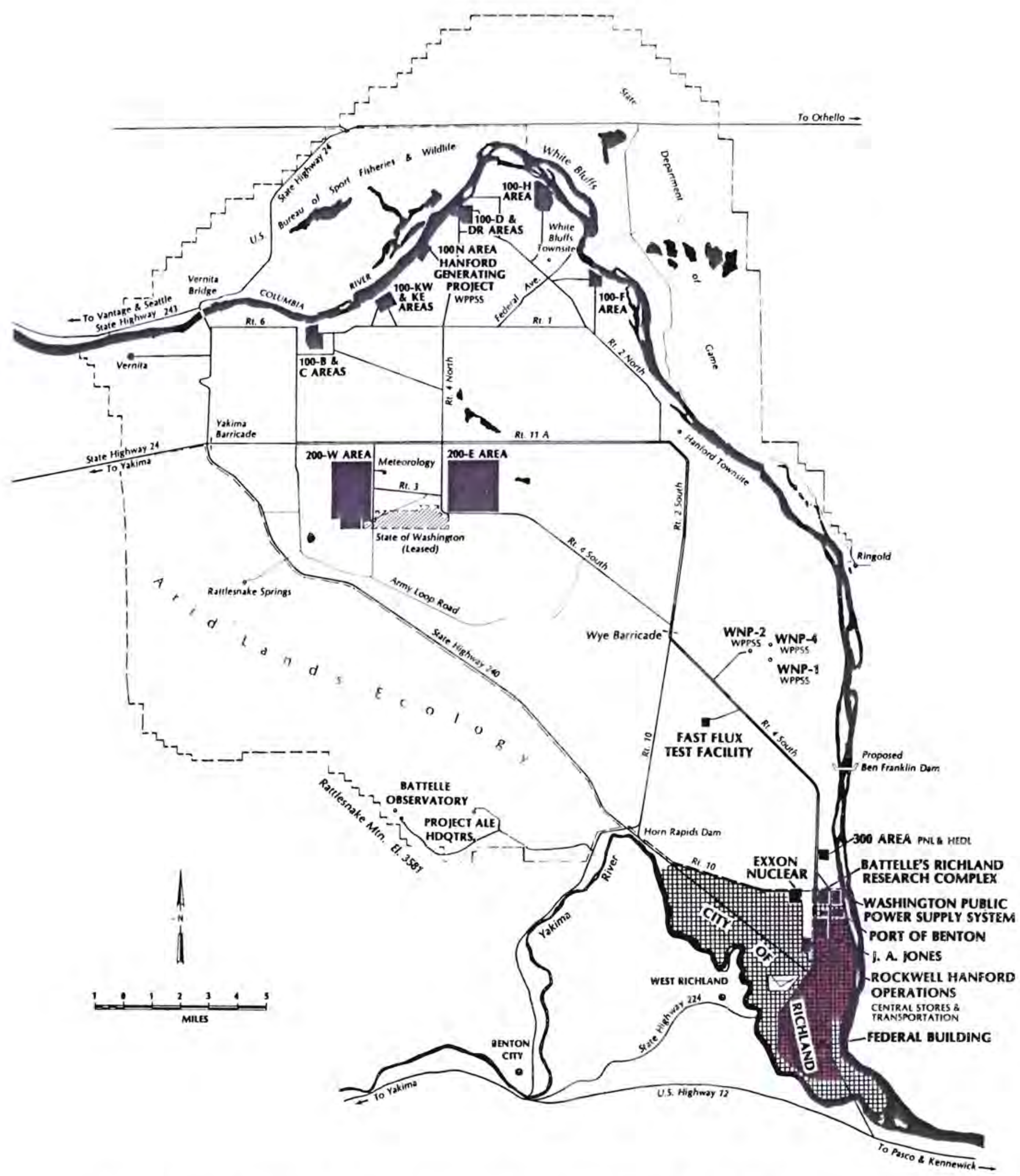

Figure 6.1 Location of District Heating Demand in the City of Richland 


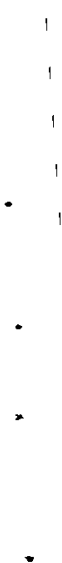


dissipated to the atmosphere. Figure 6.2 shows a simplified block flow diagram for WNP -1 .

The turbine operating cycle of WNP-1 has been optimized to extract the maximum electrical output from the system as designed. Any heat extraction from the cycle for external usage will, therefore, affect the operation of and reduce the efficiency of the system. An accurate determination of the reduction of electrical output, however, would require detailed heat balance calculations which are beyond the scope of this report.

\section{ENERGY TRANSMISSION}

We begin the analysis at the WNP-1 site, where WPPSS has estimated that the capital cost for a tie-in to the plant would be about $\$ 473,000$. At the plant boundary, the heat from one of the boiler feedwater condensate streams $\left(431^{\circ} \mathrm{F}\right)$ is transferred to a fresh water stream which has been returned from the city distribution system. The heat exchanger configuration is shown in Figure 6.3.

The $302^{\circ} \mathrm{F}$ fresh water stream is transported to the city via a 14-inch above-ground pipeline covered with 2 inches of insulation. This pipeline is assumed to run east from the WNP-1 site to the Columbia River, then south along the edge of the river to the city. The temperature drop calculated for this 12mile transmission pipe is only $6^{\circ} \mathrm{F}$, thus the water arrives at the city at a temperature of about $296^{\circ} \mathrm{F}$. The spent hot water is rejected from the individual residences at $100^{\circ} \mathrm{F}$ and returned to the heat exchanger at the WNP1 site boundary. By the time that this reject water reaches the heat exchanger, its temperature has dropped to about $89^{\circ} \mathrm{F}$.

\section{ENERGY DISTRIBUTION}

The City of Richland was divided into 18 residential heating districts as follows: 


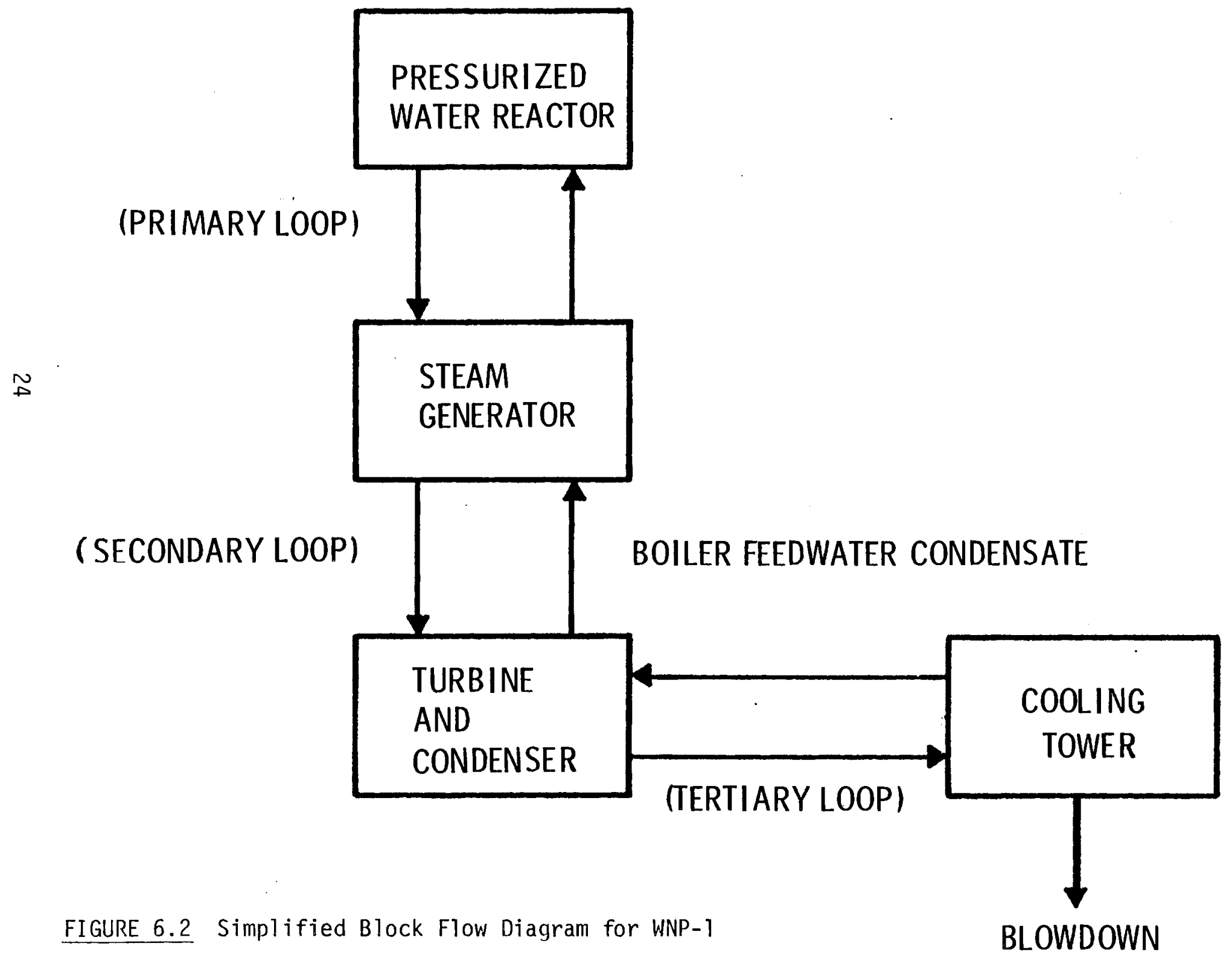




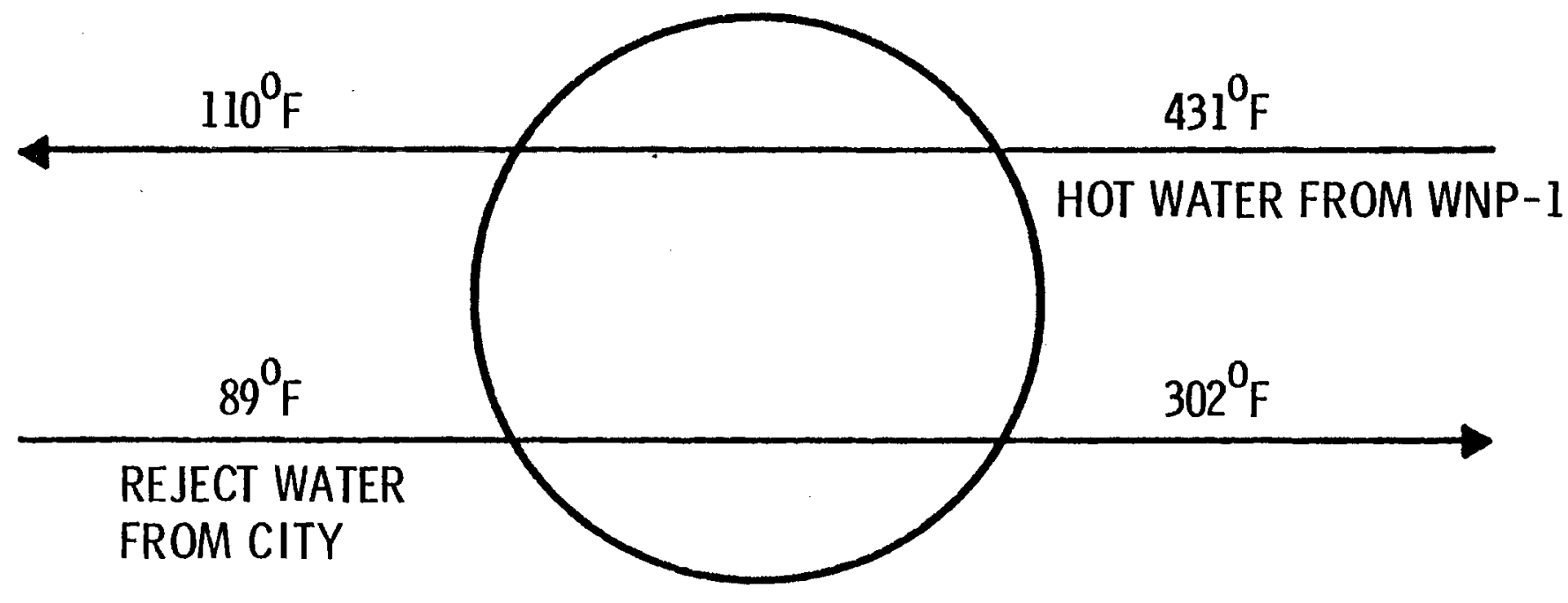

FIGURE 6.3 Heat Exchanger at WNP-1 Boundary for District Heating in the City of Richland 
1 single-family, low-density

5 single-family, medium-density

7 single-family, high-density

3 multiple-family apartments

$\underline{2}$ trailer courts

18 total

The characteristics of each district type are shown in Table 6.1. The housing densities used in this report are based on the City of Richland's zoning ordinances. The peak heat demands and hot water demands are based on ASHRAE design recommendations ${ }^{(6.1)}$. The simulation consisted of 8,460 single-family dwellings, 2,155 apartment units, and 450 mobile homes. This represents a total population of about 29,435 , assuming 2.66 people per house according to the 1970 census.

Figure 6.4 shows the layout of the 18 heating districts in Richland. The GEOCITY model requires that all districts have rectangular shapes, so the actual City of Richland zoning map was modified to conform with this requirement. The width, length, and area of each of the 18 districts were input data to the model. In addition, the length of the mains serving the districts were needed. The layout of the mains is a somewhat arbitrary choice. As shown in Figure 6.4 , we used a total of 9 mains in the simulation. CLIMATE

Climate affects district heating costs through two factors -- the minimum exterior temperature and the heating degree-days. The minimum temperature establishes the peak-load heating requirements and thus determines the size and cost of the pipes. Lower exterior temperatures require more flow and larger pipes. Larger pipes increase the capital cost of the system. For economic reasons, district heating systems are usually designed to meet less than the peak demand. The peak heating requirements are then met with supplemental 
TABLE 6.1 Characteristics of Richland District Types

\begin{tabular}{|c|c|c|c|}
\hline District Type & $\begin{array}{c}\text { Density, } \\
\text { Buildings/mi } \\
\end{array}$ & $\begin{array}{c}\text { Building } \\
\text { Peak Heat } \\
\text { Demand, } \\
10 \text { BTU } / \mathrm{hr} \\
\end{array}$ & $\begin{array}{c}\text { Building } \\
\text { Hot Water } \\
\text { Demand, } \\
\text { Gallons/Day } \\
\end{array}$ \\
\hline $\begin{array}{l}\text { Single-family, } \\
\text { low-density }\end{array}$ & 1568 & .053 & 60 \\
\hline $\begin{array}{l}\text { Single-family, } \\
\text { medium-density }\end{array}$ & 2093 & .044 & 60 \\
\hline $\begin{array}{l}\text { Single-family } \\
\text { high-density }\end{array}$ & 3837 & .034 & 60 \\
\hline $\begin{array}{l}\text { Mult iple-f ami ly } \\
\text { apartments }\end{array}$ & 376 & .480 & 1260 \\
\hline Trailer courts & 7898 & .034 & 60 \\
\hline
\end{tabular}

(a)

21 apartments per building 
FIGURE 6.4 Layout of Heating Districts in Richland

RESIDENTIAL DISTRICT TYPE

SINGLE-FAMILY, LOW-DENSITY

ZZJ SINGLE-FAMILY, MEDIUM-DENSITY

SINGLE-FAMILY, HIGH-DENSITY

MULTIPLE-FAMILY APARTMENTS

TRAILER COURTS

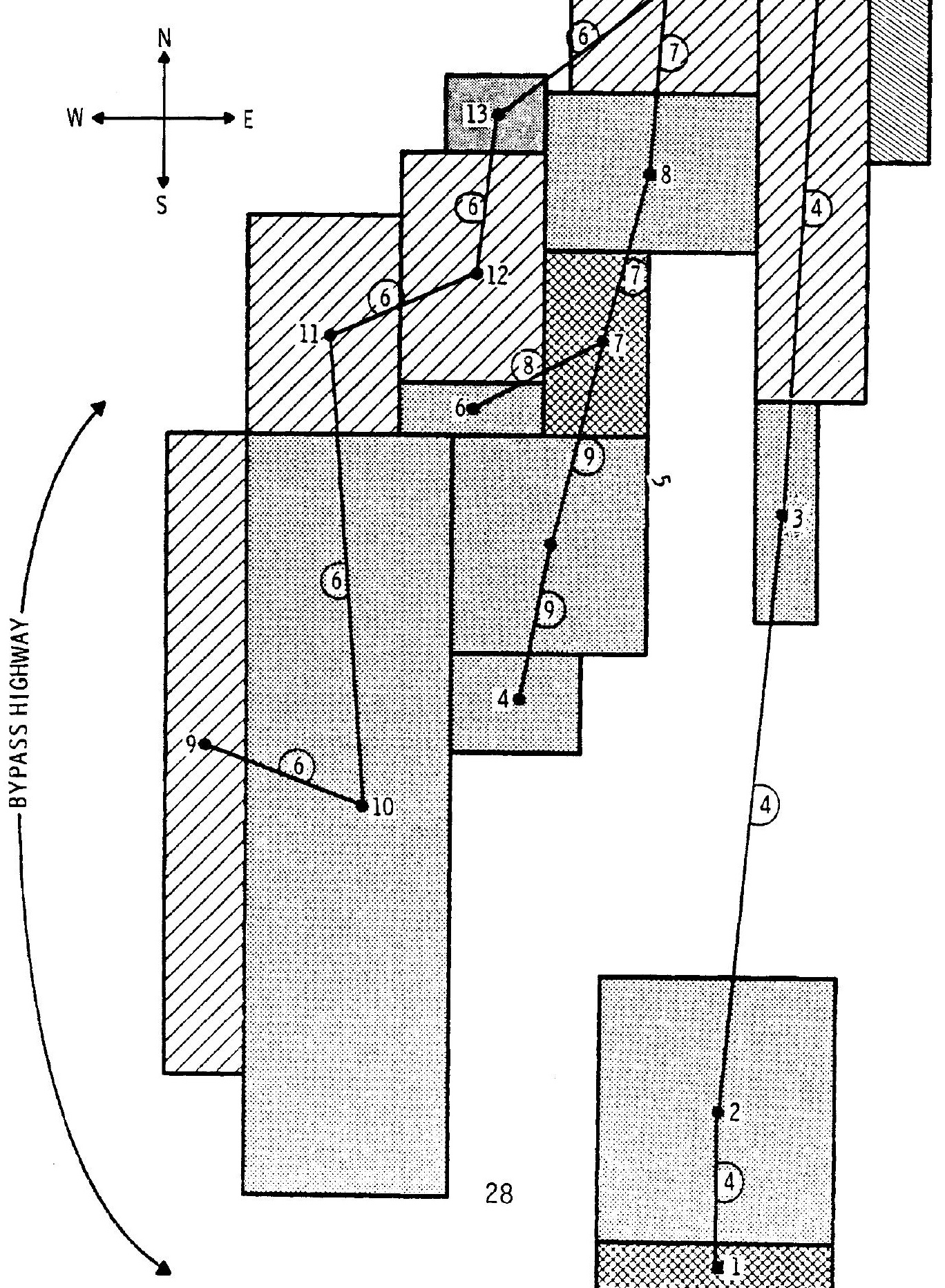

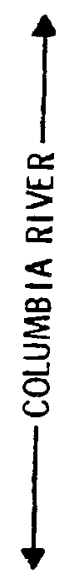


heat. The minimum temperature used to design the Richland system was $-5^{\circ} \mathrm{F}$. The district heating system was assumed to supply 97 percent of the annual heat demand (92 percent of the peak), with supplemental heat providing the remaining 3 percent of the annual demand ( 8 percent of the peak).

The number of heating degree-days establishes the annual energy usage. In cold maritime climates, such as Iceland, the annual energy usage is high and relatively constant throughout the year. The average load factor on the Icelandic systems is about $50 \%$ of system capacity. In temperate climates, the average annual energy usage is less and the systems would operate at lower load factors. The load factor on the Richland system was calculated to be only 0.31 . Since district heating systems are very capital-intensive, reductions in system capacity utilization, as reflected by degree-days, lead directly to higher energy costs. Richland has a total of 5267 heating degree-days. POPULATION AND POPULATION DENSITY

The total population of the district influences district heating costs in two ways. First, with increasing population, economies-of-scale are realized in the piping for the distribution network. Second, with increasing population, economies-of-scale are realized in the transmission piping. Thus, population growth in Richland will help to lower the unit cost of district heating.

Population density is one of the most important factors affecting district heating costs. Increasing population density reduces district heating costs through reducing the average length of pipe run. With very high population densities, as in large multi-story apartment buildings, economies-of-scale are realized in the distribution system through the use of larger-diameter pipe. Thus, future growth in high-density developments will make district heating an even more attractive option for Richland. 
Chapter 6. FOOTNOTES

6.1 McDonald, C. L., Bloomster, C. H., and Schulte, S. C. GEOCITY: A Computer Code for Calculating Costs of District Heating Using Geothermal Resources (BNWL-2208). Rich? and, Washington: Pacific Northwest Laboratory, 1977. 
Chapter 7. PROCESS HEATING COSTS FOR THE LAMB-WESTON POTATO PROCESSING PLANT

SUMMARY

We determined the cost of process heating in Richland using hot water from the WNP-1 reactor to provide process heat to the Lamb-Weston potato processing plant, which is near the Richland Airport. The approximate location of this plant, about 11 miles south of WNP-1, is shown in Figure 7.1.

For this process heating simulation, the total cost of heat was $\$ 19.13 / \mathrm{milli}$ ion BTU. The cost of purchased thermal energy from WPPSS accounts for $55 \%$ of the total cost. The capital and operating costs of the transmission and return pipes account for $45 \%$ of the total cost.

The Lamb-Weston plant currently uses either natural gas or fuel oil to fire the boilers. The block rates for natural gas range from $\$ 4.00 / \mathrm{million}$ BTU to $\$ 5.20 /$ million BTU. Fue 1 oil costs about $\$ 7.00 / \mathrm{million}$ BTU. Assuming an $85 \%$ boiler efficiency, this amounts to $\$ 4.71-\$ 6.12 / \mathrm{mi} 11$ ion BTU for natural gas and $\$ 8.24 / m i l l i o n$ BTU for fuel oil. The prices of both natural gas and fuel oil can probably be expected to escalate in the future. However, providing process heat from WNP-1 to the Lamb-Weston plant alone does not appear to be practical in the near future, since both the fluid demand and the $\Delta T$ utilized are too low.

ENERGY TRANSMISSION

We begin the analysis at the WNP-1 site, where WPPSS has estimated that the capital cost for a tie-in to the plant would be about $\$ 473,000$. At the plant boundary, the heat from one of the boiler feedwater condensate streams $\left(431^{\circ} \mathrm{F}\right)$ is transferred to a fresh water stream which has been returned from the potato processing plant. The heat exchanger configuration is shown in Figure 7.2 . 


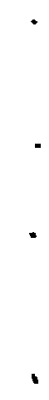




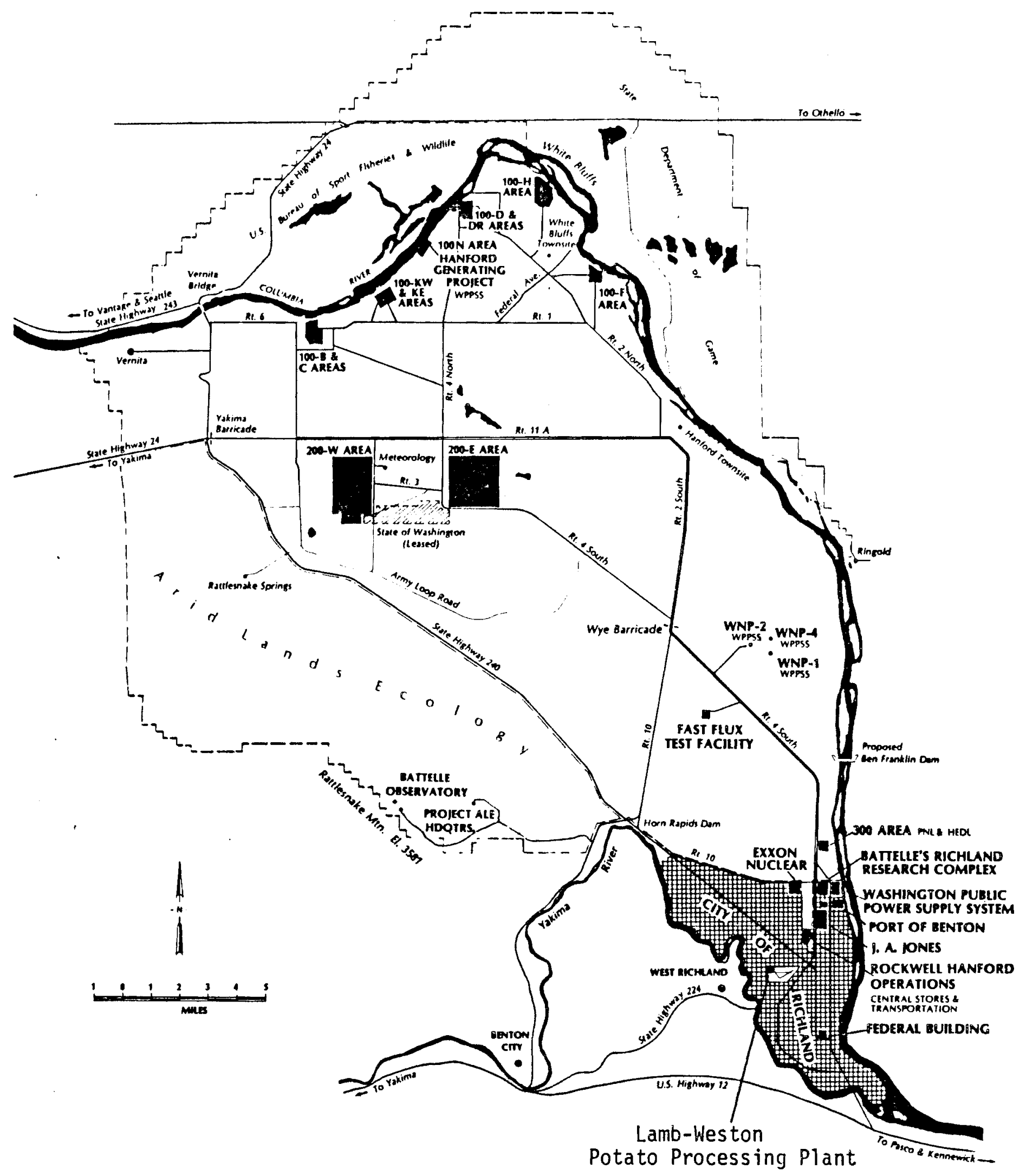

Figure 7.1 Location of the Lamb-Weston Potato Processing Plant

\section{HANFORD SITE \\ Department of Energy}




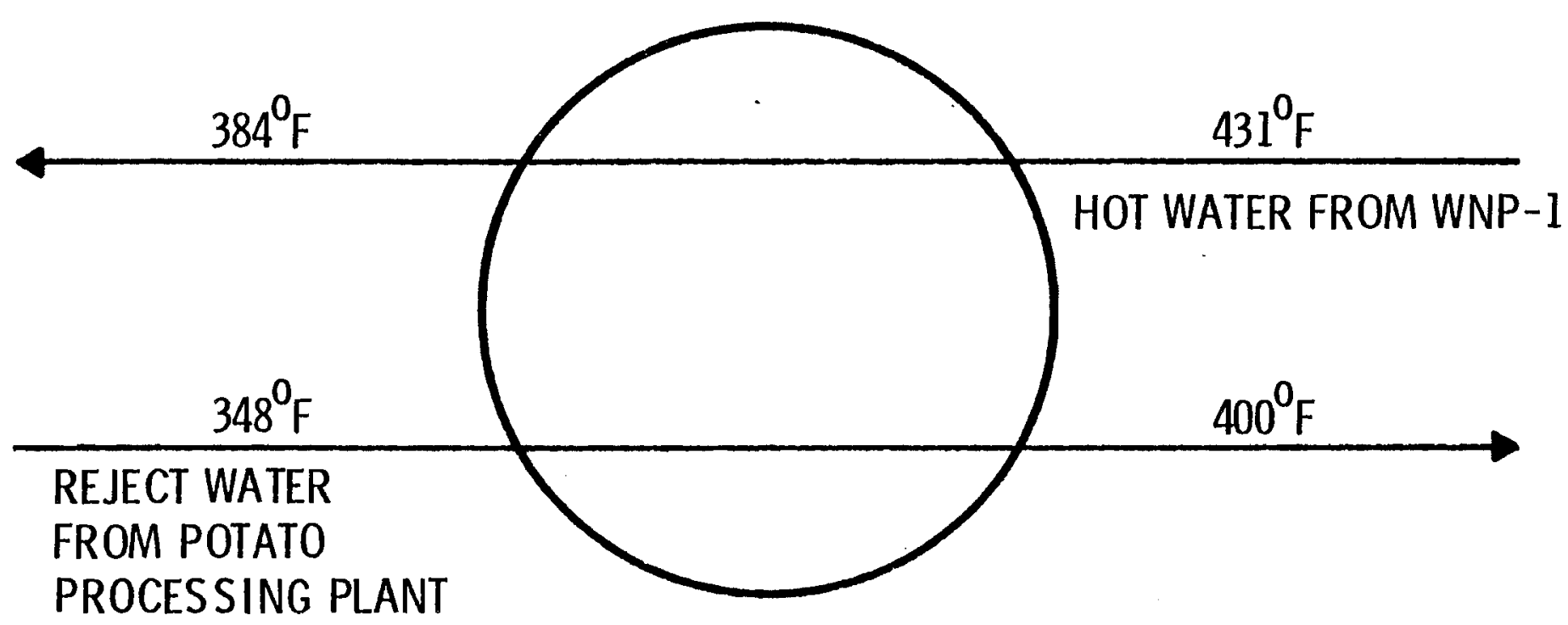


The $400^{\circ} \mathrm{F}$ fresh water stream is transported to the potato processing plant via a 12-inch above-ground pipeline covered with 2 inches of insulation. This pipeline is assumed to run in a direct straight line from WNP-1 to the potato processing plant. The temperature drop calculated for this 11-mile transmission pipe is $12^{\circ} \mathrm{F}$, thus the water arrives at the potato processing plant at a temperature of about $388^{\circ} \mathrm{F}$.

The temperature drop for this process heating transmission pipe is twice as large as that of the district heating transmission pipe described in Chapter 6. The reason is that the district heating transmission pipe has a 14-inch diameter, while this pipe has only a 12-inch diameter. The higher surface-tovolume ratio results in a higher heat loss, as a greater portion of the fluid comes into contact with the pipe walls.

STEAM REQUIREMENTS AT THE PLANT

The hot water is flashed to steam at the potato processing plant. The flash conditions are shown in Figure 7.3 . The $361^{\circ} \mathrm{F}$ reject water from the flash is returned to the heat exchanger at the WNP-1 site boundary. By the time that this reject water reaches the heat exchanger, its temperature has dropped to about $348^{\circ} \mathrm{F}$.

The potato processing plant has a peak heat demand of $28.68 \times 10^{6}$ BTU/hour, in the form of $140 \mathrm{PSIG}$ steam (saturation temperature $=361^{\circ} \mathrm{F}$ ). Space heating requirements of the plant are insignificant by comparison. The plant operates about 10 months of the year, 24 hours per day, which yields an annual load factor of 0.83 . In other words, the plant operates at full capacity for $83 \%$ of the year.

In addition to the process steam demand described above, the plant has a demand for high-pressure steam. The peak demand for high-pressure steam is about $36,000 \mathrm{lb} / \mathrm{hr}$ of $265 \mathrm{PSIG}$ steam (saturation temperature $=411^{\circ} \mathrm{F}$ ). The WNP-1 hot water source is not hot enough to satisfy this high-pressure steam 


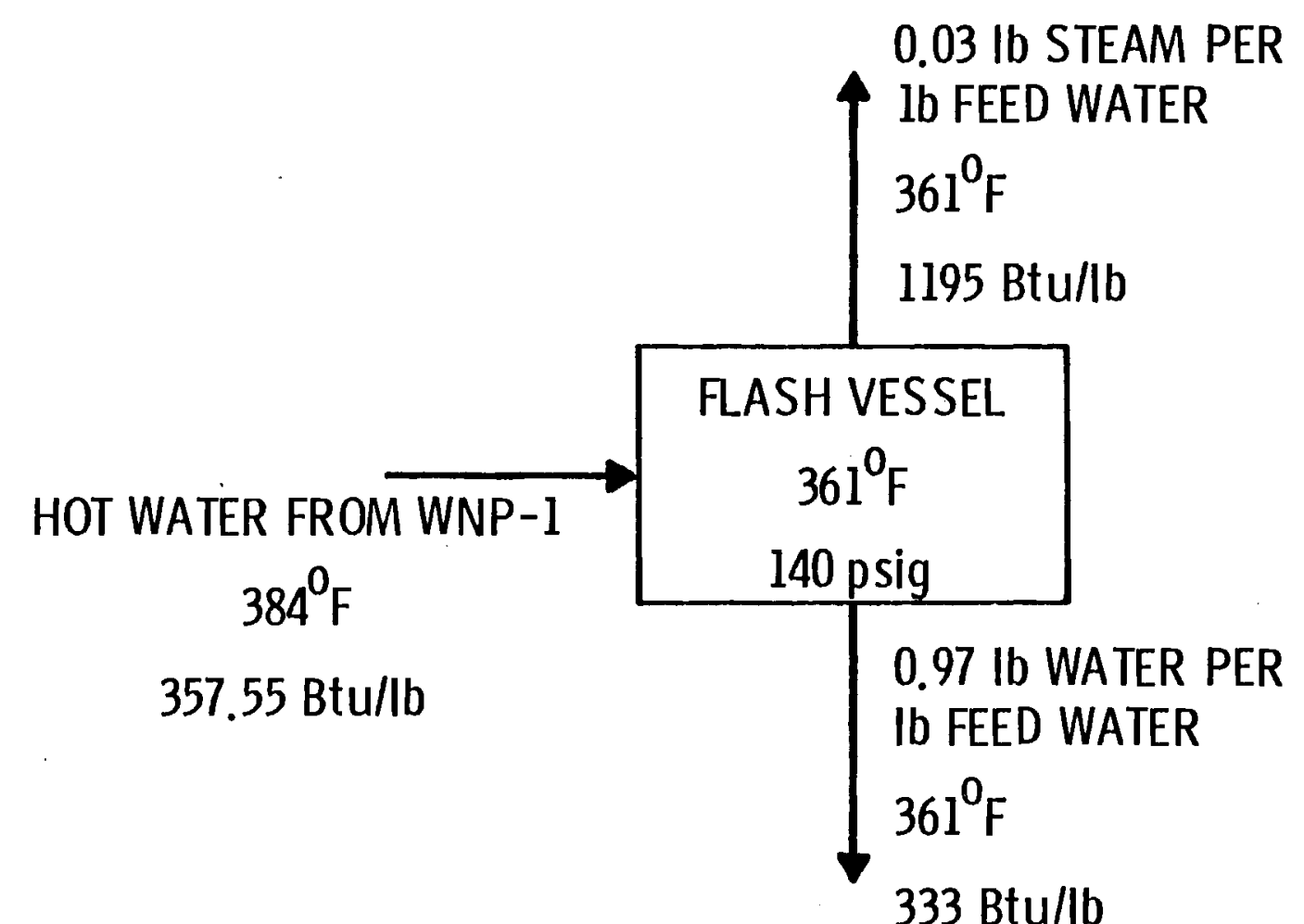

FIGURE 7.3 Flash Conditions at Potato Processing Plant 
demand, so the simulation includes only enough hot water to satisfy the demand for 140 PSI steam. However, the economics could probably be improved by supplying additional hot water to be used as boiler feedwater preheat. 
Chapter 8. DISTRICT HEATING COSTS FOR THE HORN RAPIDS TRIANGLE AREA

\section{SUMMARY}

We determined the cost of residential space heating in the Horn Rapids Triangle area. Figure 8.1 shows the location of this area, about 8.5 miles southwest of WNP-1. The Horn Rapids Triangle area is currently undeveloped, al though residential development may begin this summer ${ }^{(8.1)}$. The simulation of future residential development was based on the City of Richland's Land Use Plan.

For this simulation, the total cost of heat was $\$ 15.41 / 10^{6}$ BTU. The cost of purchased thermal energy from WPPSS accounts for $42 \%$ of the total cost. The costs of the initial investment in the transmission pipe and the distribution system, interim capital replacements, and operating expenses account for $58 \%$ of the total cost. It is estimated that $3.5 \times 10^{11}$ BTU/year of the WNP-1 heat could be utilized in district heating in the Horn Rapids Triangle. Peak demand of the district heating system would be $1.28 \times 10^{8}$ BTU/hour. The cost of district heating in the Horn Rapids Triangle area is 18\% lower than the marginal cost of electric resistance heating.

\section{ENERGY.TRANSMISSION}

We begin the analysis at the WNP-1 site, with the $\$ 473,000$ capital cost for a tie-in to the plant. At the plant boundary, the heat from one of the boiler feedwater condensate streams $\left(431^{\circ} \mathrm{F}\right)$ is transferred to a fresh water stream which has been returned from the Horn Rapids Triangle distribution system. The heat exchanger configuration is shown in Figure 8.2.

The $302^{\circ} \mathrm{F}$ fresh water stream is transported to the Horn Rapids Triangle via a 10-inch above-ground pipeline covered with 2 inches of insulation. The pipeline is assumed to run in a direct straight line from WNP-1 to the northwest end of the Horn Rapids Triangle residential area. The temperature 


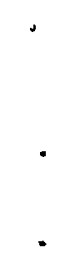




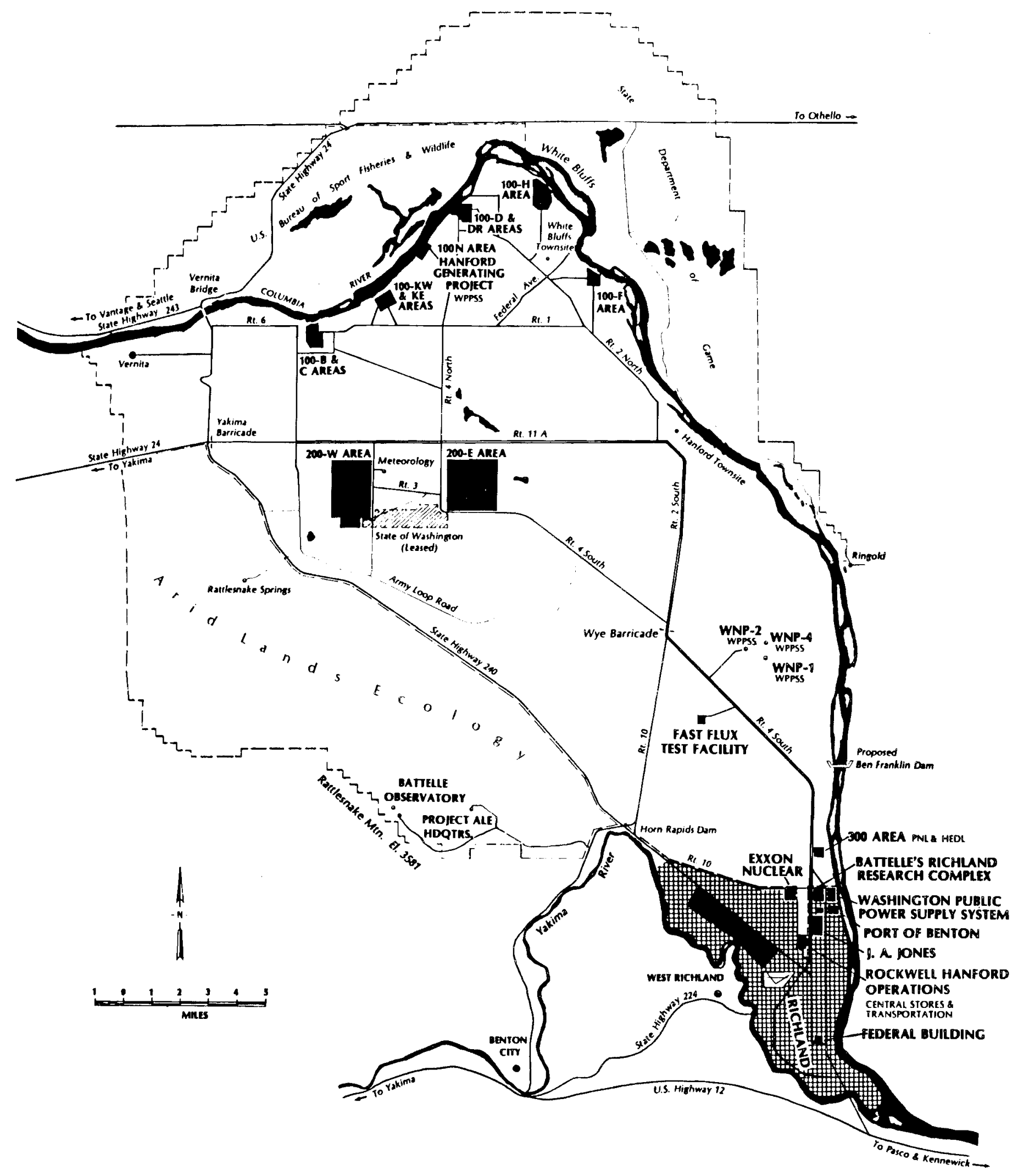

Figure 8.1 Location of Horn Rapids Triangle Area

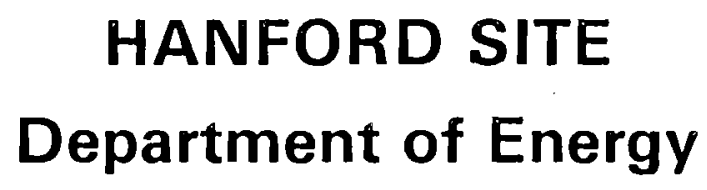




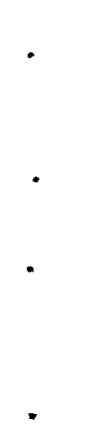




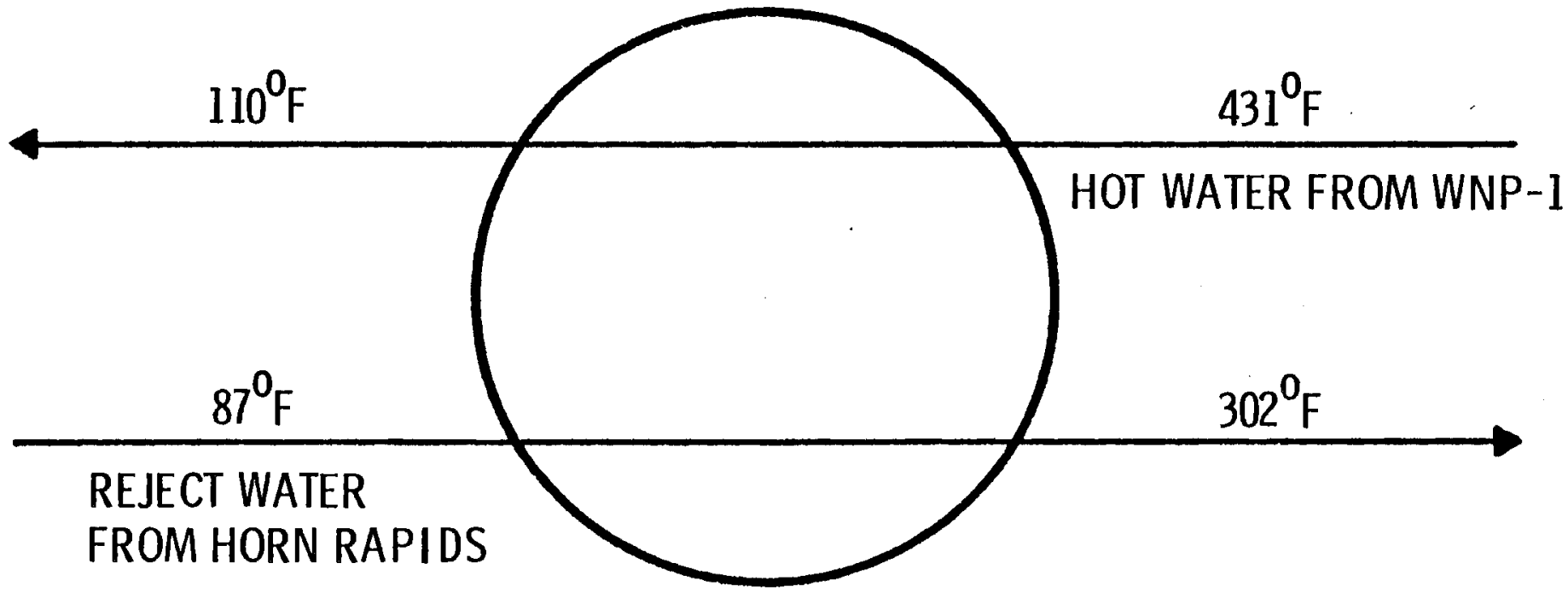

FIGURE 8.2 Heat Exchanger at WNP-1 Boundary for District Heating in the Horn Rapids Triangle Area 
drop calculated for this transmission pipe is $8^{\circ} \mathrm{F}$, thus the water arrives at the Horn Rapids Triangle at a temperature of about $294^{\circ} \mathrm{F}$. The spent hot water is rejected from the individual residences at $100^{\circ} \mathrm{F}$ and returned to the heat exchanger at the WNP-1 site boundary. By the time that this reject water reaches the heat exchanger, its temperature has dropped to about $87^{\circ} \mathrm{F}$. ENERGY DISTRIBUTION

The City of Richland's Comprehensive Land Use Plan shows the planned residential development in the Horn Rapids Triangle to consist of a mixture of high, medium, and low-density dwelling units. For this simulation we assumed one 810-acre district (1.26 square miles) with an average housing density of 3514 buildings per square mile. This is close to the housing density that we used for single-family, high-density districts in the Richland simulation. Therefore, we also used the corresponding building peak heat demand and hot water demand that we used for the single-family, high-density districts in Richland. The simulation consisted of 4428 dwellings, representing a population of 11,778 . 


\section{Chapter 8. FOOTNOTES}

8.1 Tri-City Herald, Rich1and, WA, January 20, 1981. 
Chapter 9. PROCESS HEATING COSTS FOR THE 300 AREA

\section{SUMMARY}

We determined the cost of process heating in the 300 area of the Department of Energy's Hanford Site using hot water from the WNP-1 reactor. The location of the 300 area, about 7 miles south of WNP-1, is shown in Figure 9.1.

The 300 area has a peak demand of $160 \times 10^{6}$ BTU/hour, in the form of 120 PSIG steam (saturation temperature $=350^{\circ} \mathrm{F}$ ). The annual load factor is about 0.36. For this simulation, the total cost of heat was $\$ 10.87 / \mathrm{mi} 11$ ion BTU. The cost of purchased thermal energy from WPPSS accounts for $60 \%$ of the total cost. The capital and operating costs of the transmission and return pipes account for $40 \%$ of the total cost. Using hot water from WNP-1 for process heating in the 300 area is not competitive with the cost of either oil or coal, the currently used fuels.

\section{ENERGY TRANSMISSION}

We begin the analysis at the WNP-1 site, with the $\$ 473,000$ capital cost for a tie-in to the plant. At the plant boundary, the heat from one of the boiler feedwater condensate streams $\left(431^{\circ} \mathrm{F}\right)$ is transferred to a fresh water stream which has been returned from the 300 area. The heat exchanger configuration is shown in Figure 9.2 .

The $400^{\circ} \mathrm{F}$ fresh water stream is transported to the 300 area via a 20 -inch above-ground pipeline covered with 2 inches of insulation. This pipeline is assumed to run east from the WNP-1 site to the Columbia River, then south along the edge of the river to the 300 area. The temperature drop calculated for this 9-mile transmission pipe is only $5^{\circ} \mathrm{F}$, thus the water arrives at the 300 area at a temperature of $395^{\circ} \mathrm{F}$. 


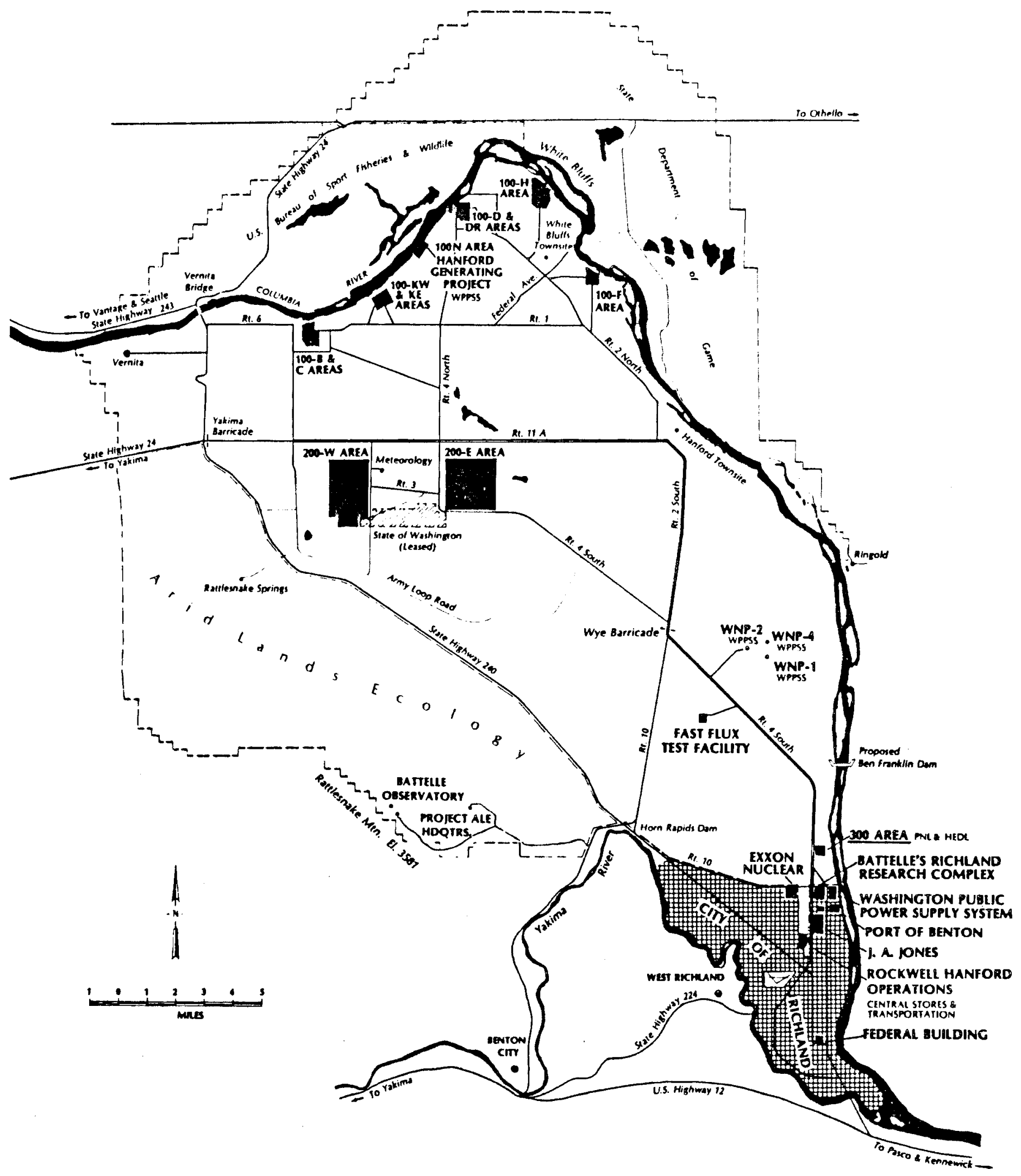

Figure 9.1 Location of the 300 Area

\author{
HANFORD SITE \\ Department of Energy
}




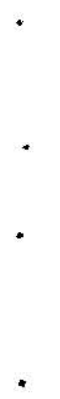




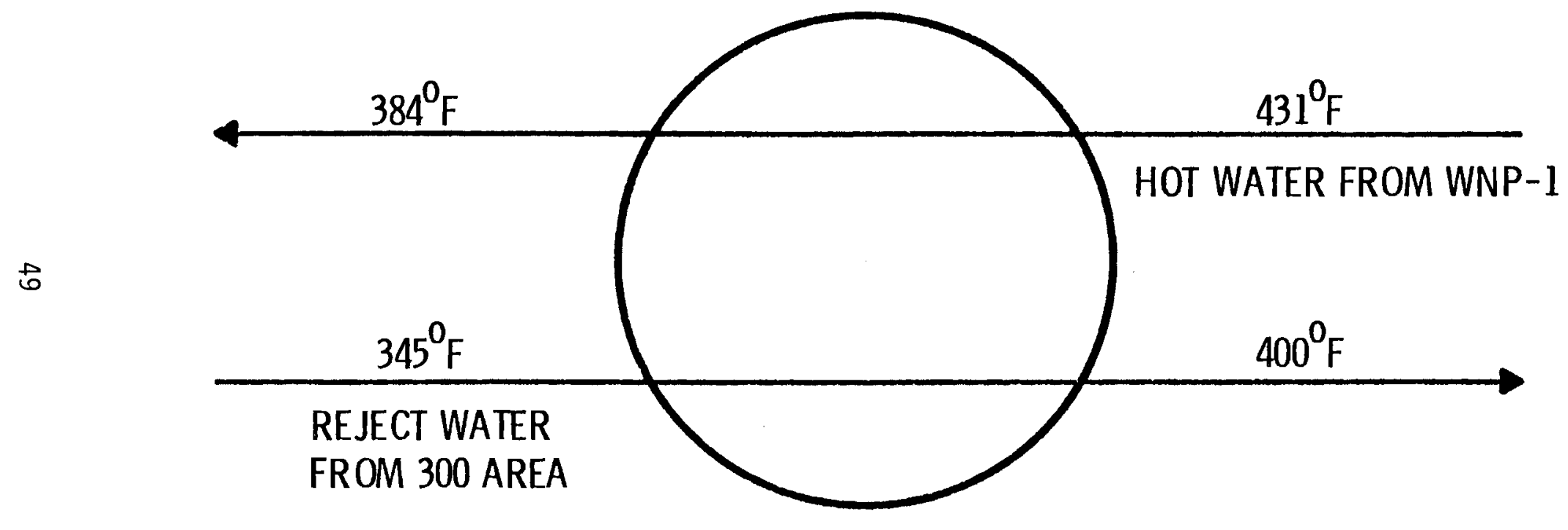

FIGURE 9.2 Heat Exchanger at !NP-1 Boundary for Process Heating in the 300 Area 


\section{STEAM REOUIREMENTS IN THE 300 AREA}

The hot water is flashed to steam at the 300 area. The flash conditions are shown in Figure 9.3. The $350^{\circ} \mathrm{F}$ reject water from the flash is returned to the heat exchanger at the WNP-1 site boundary. By the time that this reject water reaches the heat exchanger, its temperature has dropped to about $345^{\circ} \mathrm{F}$. COMPARISON WITH THE VITRO STUDY

In 1982 or 1983, DOE plans to replace 5 of the 6 boilers currently in operation in the 300 area. The boilers now use $80 \%$ coal at a price of about $\$ 6.00 / \mathrm{million}$ BTU and $20 \%$ oil at an average price of over $\$ 7.00 / \mathrm{million}$ BTU. Assuming an $85 \%$ boiler efficiency, this amounts to $\$ 7.06 / m i 1 l i o n$ BTU for coal and $\$ 8.24 / \mathrm{milli}$ ion BTU for $0 i 1$. Before making the final commitment to purchase the new boilers, DOE requested that the Hanford Engineering Development Laboratory (HEDL) evaluate other alternatives, including the use of hot water from one of the WPPSS reactors. HEDL subcontracted with Vitro Engineering Corporation to do the study.

The Vitro study ${ }^{(9.1)}$ evaluated three options:

(1) Transmission of hot water from WNP-1 to the 300 area and generation of steam in the 300 area.

(2) Generation of steam at the WNP-1 site and transmission of steam to the 300 area.

(3) Transmission and use of pressurized hot water.

The conclusion reached was that due to the high capital costs, it was not economically feasible to use the WNP-1 hot water as a replacement heat source for the 300 area.

Our results agree with this assessment. However, we do not advocate a system that would supply heat only to the 300 area. We feel that the hot water must be cascaded from the highest-temperature demand to the lowest-temperature demand in order to extract the maximum energy per pound of water. Our proposed 


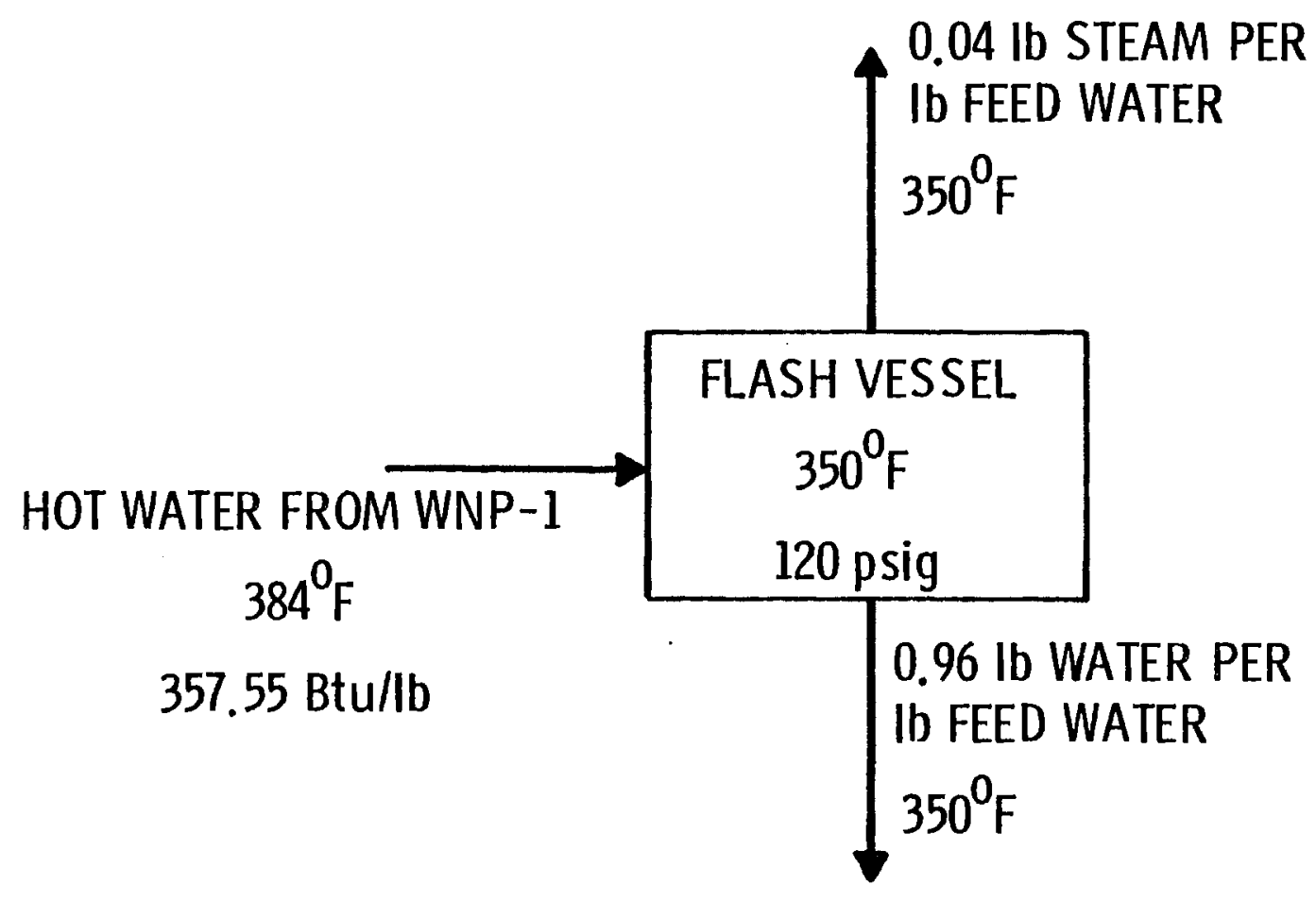


system would supply $400^{\circ} \mathrm{F}$ water to the 300 area. The $350^{\circ} \mathrm{F}$ reject water from the 300 area would then be used in the 3000 area. Finally, the $302^{\circ} \mathrm{F}$ reject water from the 3000 area would be used for district heating in the City of Richland. This scheme results in an overall cost of heat of $\$ 8.46 / \mathrm{million}$ BTU, which is quite competitive with conventional heating costs, as discussed in Chapter 11. 


\section{Chapter 9. FOOTNOTES}

9.1 Ka11io, V. J. WPPSS Hot Water Use Study-300 Area Steam Plant (EE1074). Richland, Washington: Vitro Engineering Corporation (prepared for Hanford Engineering Development Laboratory), September 1980. 
We determined the cost of process heating in the Battelle buildings in the 3000 area in north Richland. The location of the 3000 area, about 1.5 miles south of the 300 area, is shown in Figure 10.1.

The 3000 area has a peak demand of about $25.232 \times 10^{6}$ BTU/hour, and an annual load factor of 0.31 . Although the heating requirements of the 3000 area were simulated as a process heat demand (for simplicity), the demand is actually for space heating of the office buildings. For this simulation, the total cost of heat was only $\$ 3.13 /$ million BTU. This cost is very low because the reject hot water from the 300 area is assumed to be free. That is, the cost of purchased thermal energy from WNP-1 was included in the cost of heat for the 300 area, but not in the cost of heat for the 3000 area. The combined cost of process heating in the 300 and 3000 areas is $\$ 9.94 / \mathrm{million}$ BTU, which appears to be competitive.

The $350^{\circ} \mathrm{F}$ reject water stream from the 300 area is transported to the 3000 area via a 10-inch above-ground pipeline covered with 2 inches of insulation. The temperature drop calculated for this 1.5-mile transmission pipe is on $7 y 2^{\circ} \mathrm{F}$, thus the water arrives at the 3000 area at a temperature of about $348^{\circ} \mathrm{F}$. 


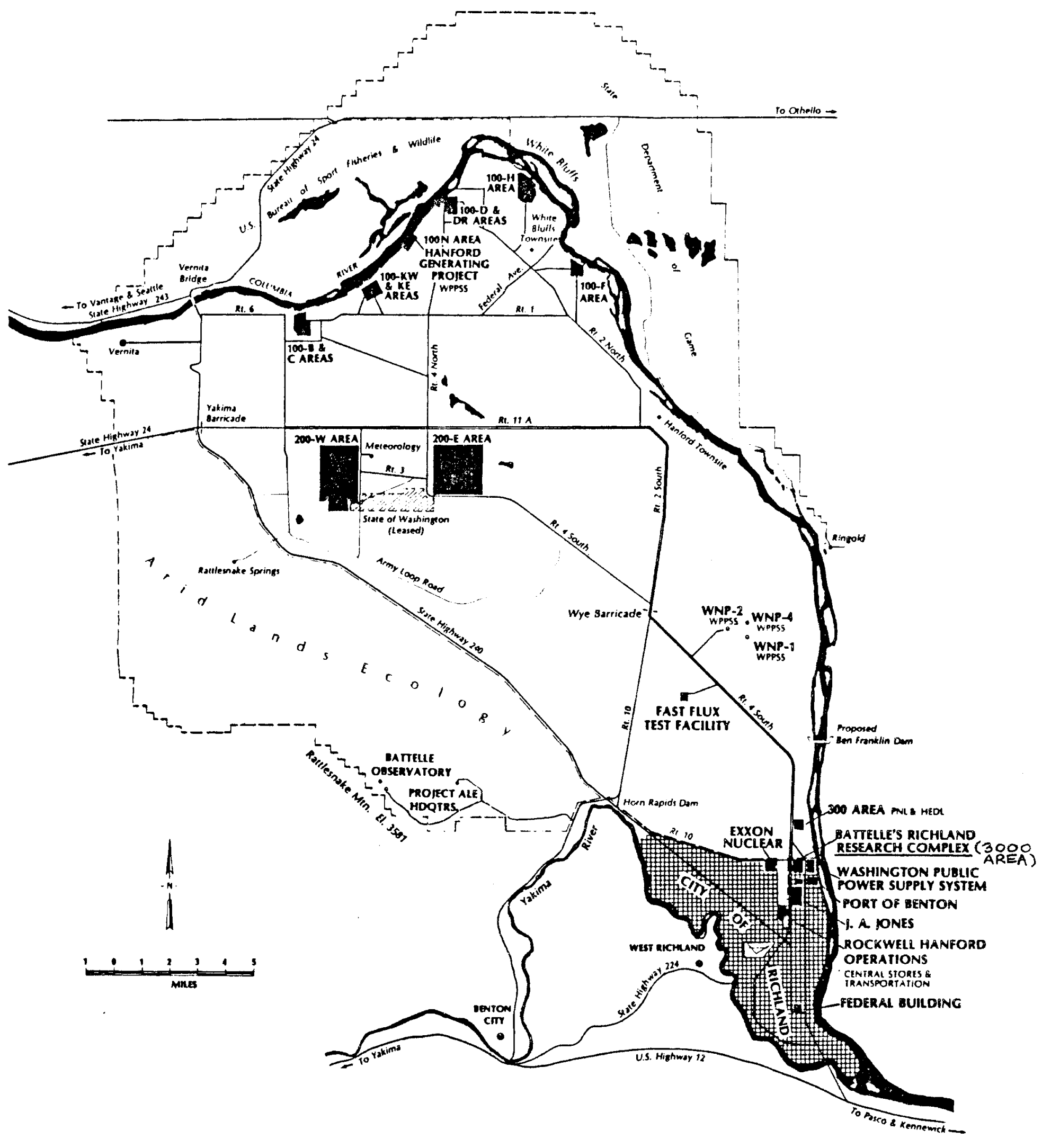

Figure 10.1 Location of the 3000 Area

\author{
HANFORD SITE \\ Department of Energy
}




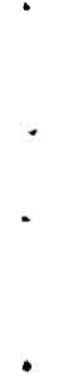




\section{Chapter 11. ECONOMIC ANALYSIS}

SUMMARY

The simulation of the combination of all of the district and process heating applications resulted in an overall cost of heat of $\$ 9.17 / \mathrm{million}$ BTU. This is only $15 \%$ more than the expected average cost of electricity in Richland by 1985, which provides a strong incentive for performing a much-more-detailed feasibility analysis of such a system. Using the system for district cooling in the summer and building energy storage capacity into the system should also be investigated, since these actions would serve to further decrease the unit cost of heat to the consumer.

AVERAGE COST AND MARGINAL COST

Through price controls, regulations, and other market forces, conventional residential heating prices tend to be based on recovering the average costs of production rather than on marginal-cost pricing. That is, the higher costs of providing heat to new areas or from new conventional energy sources are "rolled in" with the production and distribution costs from existing sources. Averagecost pricing presents a significant barrier to market penetration by new energy sources which, in the absence of subsidies, must be priced on a marginal-cost basis since there is no existing production and distribution. However, with time the marginal costs of conventional fuels will predominate and the new energy sources will become competitive.

For example, the current price of electricity in Richland is about 20 mills $/$ kWh $\left(\$ 5.86 / 10^{6}\right.$ BTU). This is the average cost of electric power generation, and it is largely a function of the inexpensive hydroelectric power base in the Pacific Northwest. By 1985, when WNP-1 will be in operation, the average cost of power in Richland is expected to be about $27.5 \mathrm{mills} / \mathrm{kWh}$ $\left(\$ 8.00 / 10^{6}\right.$ BTU $)$. However, the expected marginal cost of generating 
electricity from WNP-1 is $61.9 \mathrm{mills} / \mathrm{kWh}\left(\$ 18.14 / 10^{6} \mathrm{BTU}\right)$. This is a 30 -year levelized busbar cost in 1980 dollars. To convert this busbar cost into a delivered cost to the consumer, an estimated $2 \mathrm{mills} / \mathrm{kWh}$ for transmission and distribution expenses must be added to it. Thus the delivered cost of power from WNP-1 is expected to be $63.9 \mathrm{mills} / \mathrm{kWh}\left(\$ 18.73 / 10^{6} \mathrm{BTU}\right)$.

As stated in Chapter 6 , the cost of district heating in Richland would be $\$ 15.92 / 10^{6}$ BTU. This cost is less than the marginal cost for electric resistance heating calculated above. Since the marginal cost is the appropriate criterion for economic comparison, it is clear that a district heating system would be cost-effective. Since the cost of district heating is less than the marginal cost of electricity from WNP-1, it represents a net benefit to society, and should therefore be preferable to electric resistance heating.

METHODS FOR LOWERING DISTRICT HEATING COSTS

Combined applications of space heating with process heating offer the potential to lower both space heating and process heating costs: (1) through economies-of-scale, particularly in fluid transmission, and (2) through achieving a higher system load factor. The latter, of course, would be most effective if the space heating and process heating demands were contraseasonal.

Flow rate and temperature have significant impacts on the cost of energy transmission. The flow rate refers to the peak demand. The peak demand is determined by the coincident end-use demands. Since pipe costs increase roughly linearly with diameter while capacity increases with the square of the diameter, significant economies-of-scale are achieved with large pipes. Thus, a large market would tend to be served more economically than a small one.

The load factor also has a significant impact on transmission costs. The costs for fluid transmission derive mainly from the initial investment in the pipeline. Operating expenses, including pumping and maintenance, will usually 
be small. Since the principal transmission costs are fixed costs, high load factors contribute significantly to lowering the unit energy costs.

Opportunities exist for lowering the district heating costs by increasing the system load factor. This can be done by utilizing the district heating system for district cooling during the summer. It can also be done by adding energy storage capacity to the system.

By combining district and process heating applications, using the system for district cooling in the summer, and building energy storage capacity into the system, we believe that the cost of district heating could be cut in half. Such optimizations could make district heating/cooling in Richland cheaper than the average cost of electricity. In the remainder of this chapter we will assess the impact of combining all of the district and process heating applications that we described in Chapters 6-10.

\section{COST OF COMBINED DISTRICT AND PROCESS HEATING}

The GEOCITY model was used to determine the cost of the combination of district heating in the City of Richland and the Horn Rapids Triangle area, plus process heating at the Lamb-Weston potato processing plant, the 300 area, and the 3000 area. For this simulation we assumed that the reject water stream from the Lamb-Weston plant was used for district heating in the Horn Rapids Triangle. We also assumed that the 300 area reject water stream was used to heat the 3000 area, and that the 3000 area reject water stream was used for district heating in Richland.

This simulation required two separate transmission pipes between WNP-1 and the heat demands. An 11-mile transmission pipe was assumed to run due south from WNP-1 to the Lamb-Weston plant. The potato plant reject water is transported to the southeast end of the Horn Rapids Triangle area, a distance of about 0.5 mile. The second transmission pipe was assumed to run east from the WNP-1 site toward the Columbia River, then south to the 300 area, a total 
distance of 9 miles. The 300 area reject water is transported 1.5 miles to the 3000 area, and then the 3000 area reject water is transported 1 mile to the distribution center at the north end of Richland. Return pipes are assumed to be installed next to the transmission pipes. This piping network is shown in Figure 11.1.

As in the single applications that we looked at earlier, there is a heat exchanger at the WNP-1 boundary for each of the two transmission pipes. Again, each of these tie-ins to the plant would cost $\$ 473,000$. Th heat from one of the $431{ }^{\circ} \mathrm{F}$ boiler feedwater condensate streams is used to heat the fresh water return streams from $100^{\circ} \mathrm{F}$ up to $400^{\circ} \mathrm{F}$. (Recall that $100^{\circ} \mathrm{F}$ is the reject temperature from each of the district heating applications, which lie at the end of our cascading schemes.) 


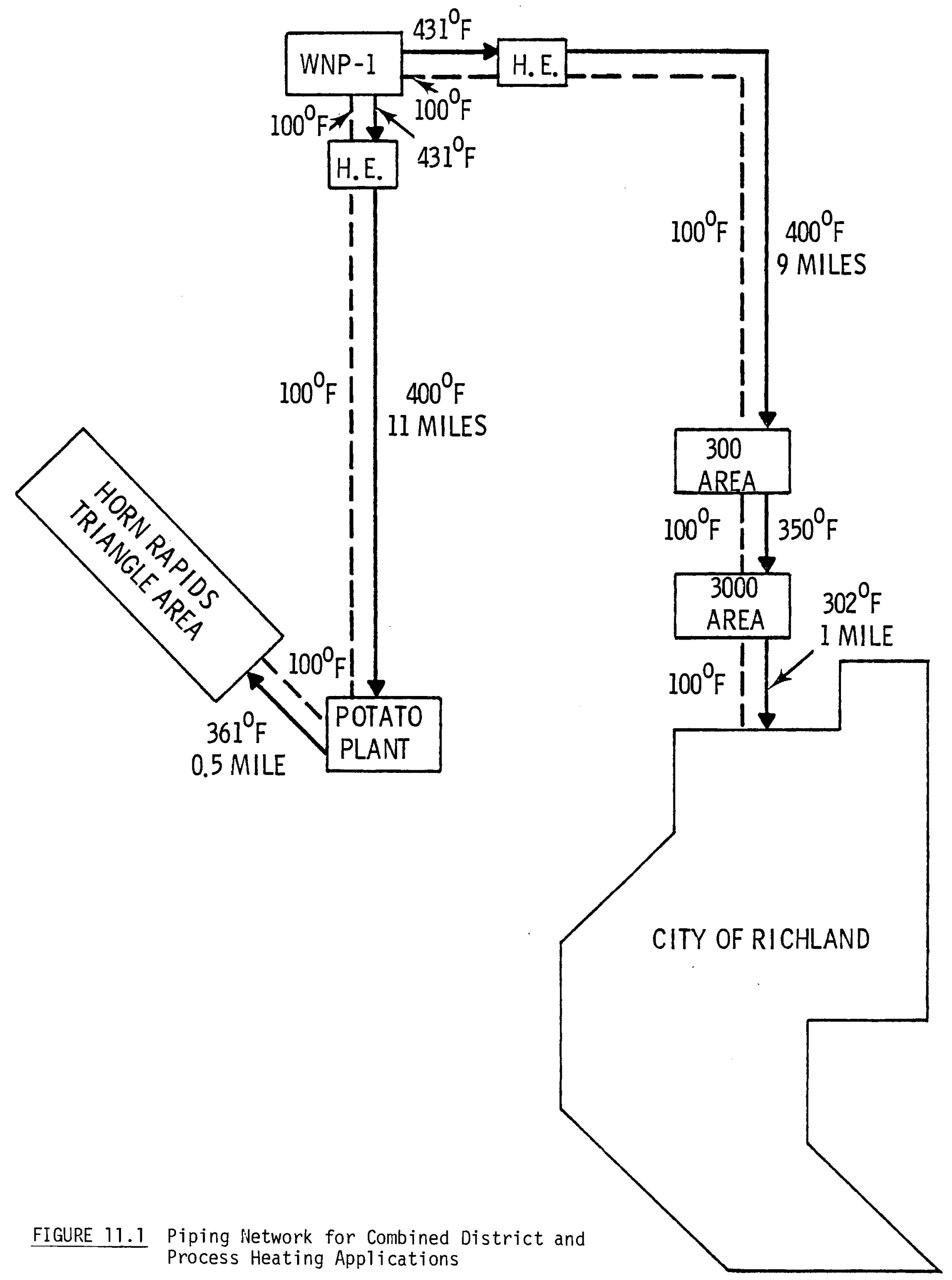


Chapter 12. INSTITUTIONAL CONSTRAINTS

SUMMARY

The major obstacles to implementation of a district heating system in Richland would probably be institutional rather than technical in nature. Institutional deterrents to district heating in Richland might be significant. Among these would be the need to organize concentrated markets, a high degree of participation within the heating district, commitment by the city of Richland (or another entity) to undertake the construction and operation of a district heating system, the availability of financing, price competition from conventional electric resistance heating based on average cost rather than marginal cost, the need to obtain the permission of over $80 \%$ of the WNP-1 participants and $2 / 3$ of the bond holders, and various regulatory and liability issues dealing with large hot water transmission pipes.

\section{GUARANTEED DEMAND}

It is critical to ensure a viable demand for the heat on a scale which makes the investment in transmission and distribution pipes economically feasible. (There are dramatic economies-of-scale in pipeline construction.) The City of Richland would need to have a guaranteed demand before it would be willing to commit to the project.

Organization of a producers' market is easy, but organization of a consumers' market is difficult. Usually the degree of consumption is determined by price competition. However, implementation of a district heating system requires a guarantee that a large block of consumers will hook up to the system before construction actually begins. In fact, a high percentage of participation is necessary for economic feasibility.

Several countries in Europe have laws which mandate the connection of al1 buildings to the district heating systems within a certain period of 
time ${ }^{(12.1)}$. In Sweden, however, hook-up to the district heating system is voluntary, but rates charged for district heating are lower than those for individual residential heating systems ${ }^{(12.2)}$. In addition, the government of Sweden pays $25 \%$ of the cost of converting heating systems and also provides lowcost loans $(12.1)$.

\section{ACTION}

No existing organization has a clear mandate or incentive for developing a district heating system. Utilities have been willing to provide hot water at the plant boundary, but do not want to distribute the energy because it would be a new type of enterprise in which they are inexperienced and because they would be competing with their electrical distribution. Private companies are unwilling to develop an enterprise which would become a regulated utility. Municipalities are resistant to taking on new enterprises, particularly those which require large initial financing, and with which there is little experience.

Rapidly-escalating prices and dwindling supplies of energy resources should convince communities that the time has come for them to form municipal utilities and begin community energy planning. Responsibility for energy policy cannot rest with the federal government. The energy and economic futures of many communities could be self-determined, provided that they can effectively act in areas in which they have not traditionally been involved $(12.4)$. As mentioned before, the city of Richland is already an experienced municipal utility operator, so it should have a head start in implementing a district heating system.

\section{FINANCING}

There are two key financing issues:

1) the extent to which potential customers will voluntarily connect to the district heating system depends on the financing available to 
defray initial connection costs, and

2) the ability of the City of Richland to raise capital in the competitive capital markets will utilmately determine whether a district heating system is ever built here.

PRICING

District heating costs are competitive with the price of new electrical generation in Richland. These costs, however, may not be competitive with the prices actually charged for the electricity. Prices charged are based on average costs, which include the costs of older and less-expensive hydroelectric supplies. Decision makers must realize that the marginal cost is the appropriate criterion for economic comparison, even though the prices actually charged the consumers represent average costs.

Another price issue is regulation of prices of certain energy sources. Regulation keeps these prices low so that consumers do not perceive the scarcity of supply and the full costs to society of the continued consumption of the energy sources. Thus, society makes inefficient choices among continued fossil fuel consumption, district heating, and conservation. Approximately $10 \%$ of the residences in Richland use either natural gas or fuel oil for space heating. Expected escalation of $0 i 1$ and gas prices should eliminate this problem.

\section{LEGAL PROBLEMS}

Major legal problems would evolve from attempting to divert BTUs from the WNP-1 steam cycle. Diversions would reduce the level of power that the system could produce. This alternate use of steam would require permission from the plant's participants (20\% negative would kill the proposal) and the permission of $2 / 3$ of the bond holders. The latter might be very difficult to achieve. On future plants, if the diversion were contracted during early planning stages, this would not be a problem. 
There would be a benefit to advanced planning with respect to use of BTUs from the steam cycle of any of the WPPSS plants. In fact, planning before initial bond issue might be the only method of obtaining high-grade hot water. However, this involves the user stating his intent twelve years in advance of the date of use and might require a 35-year contract. It is not clear that any users would be interested in such long-range planning or the possible delays that could accompany plant construction.

\section{HOT WATER TRANSMISSION}

Other major problems involve the transmission pipe, as described below.

"With the exception of oil pipelines and some surface pipeline conduits for drinking water, there are no major precedents available for either the financing or the regulation of hot water pipelines. It is likely that many new environmental standards will be necessary when considering potential impacts of piping hot water over long distances. There are also likely to be controversies over the acquisition of rights-of-way for a hot water pipeline, and liability issues related to potential ruptures of a hot water line."(1.2.4).

\section{RELIAB ILITY OF ENERGY SUPPLY}

Operational. problems could accompany use of hot water from WNP-1. With the potential for the reactor to shut down unexpectedly, the district heating system would need a backup source of hot water and control systems for changing the mode of operation. Potential backup sources include WNP-4 or possibly one of the planned Puget Power reactors. The use of seasonal thermal energy storage might preclude the need for a backup energy source. This issue must be addressed in a more-detailed feasibility study. 
12.1 McCabe, John E. and Huxtable, Douglas D. "District Heating for Bellingham, Washington Using Waste Heat from an Aluminum Plant as the Energy Source". District Heating 65(3) (January-February-March 1980): 14-21.

12.2 Mauro, Robert L. "Is Cogeneration Feasible in the US.?" Public Power (January-February 1978): 24-27.

12.3 Gleason, Jack. "District Heating Saves Energy (In Europe)". Public Power 37(5) (September-October 1979): 46-49.

12.4 Bloomster, C. H. and Schuller, C. R. "The Promise of Geothermal Energy Systems for Commun ities". Integrated Community Energy Systems P1anning. Columbus, Ohio: Battelle, Columbus Laboratories, 1979. 


\section{ACKNOWLEDGMENTS}

We would like to thank the following individuals for their kind assistance:

- Barbara Eaton (PNL) for her excellent typing.

- Sharon Engstrom (WPPSS) for providing data on the availability and pricing of the hot water, and the expected cost of power from WNP-1.

- Nei1 Harpster (Lamb-Weston) for providing data on the process heat requirements of the potato processing plant.

- Harold Harty (PNL) for guidance and encouragement.

- Harlan Huber (PNL) for modifying the GEOCITY computer model for this project.

- Larry Kimmel (PNL) for providing data on energy use at Hanford.

- Ruth Laidler (PNL) for her excellent typing.

- Gary Mabley (City of Richland) for providing data on zoning and housing densities. 


\section{BIBL IOGRAPHY}

Aamot, Haldor, W. C. "Plans for District Heating with Cogeneration in the New Alaska State Capital". District Heating 64(2) (October-November-December 1978): 22-34.

Aho, M., Hiidenpalo, H., and Seppa, M. "A Survey Investigation Concerning Nuclear District Heating Policies in the Helsinki Metropolitan Area". Nuclear Technology (April 1978).

Barnes, Michael H. and Easton, Carroll W. District Heating Business Facts for Utilities. Minneapolis, Minnesota: Research-Cottre11, 1980.

Barnes, R. W. The Potential Industrial Market for Process Heat from Nuclear Reactors. Oak Ridge, Tennessee: Oak Ridge National Laboratory, 1976.

Benson, Harold E. and Monford, Leo G. Initial Comparisons of Modular-Sized, Integrated Utility Systems and Conventional Systems for Several Building Types. Houston, Texas: National Aeronautics and Space Administration, 1976.

Beresovski, Theodore and Rubin, Alan M. "Studies Relating to Thermal Energy Supply from Central Nuclear Power Stations". District Heating 63(2)

(October-November-December 1977): 22-27.

Beresovski, T., Spiewak, I., and 0liker, I. "Urban District Heating Using Nuclear Heat - A Survey". Atomic Energy Review (1979).

Bloomster, C. H., Fassbender, L. L., and McDonald, C. L. Geothermal Energy Pntential for District and Process Heating Applications in the U.S. - An Economic Analys is (BNWL-2311). Richland, Washington: Pacific Northwest Laboratory, 1977.

Bloomster, C. H., Fassbender, L. L., Schilling, A. H., and Lippek, H. E. Survey and Preliminary Evaluation of Potential Geothermal Energy Applications for Riverside, California (PNL-2597). Richland, Washington: Pacific Northwest Laboratory, 1978.

Bloomster, C. H., Garrett-Price, B. A., and Fassbender, L. L. A Comparison of Geothermal, Solar, and Conventional Space Heating Costs in the United States (PNL-SA-8244). Richland, Washington: Pacific Northwest Laboratory, 1980.

Bloomster, C. H., Garrett-Price, B. A., and Fassbender, L. L. Residential Heating Costs - A Comparison of Geothermal, Solar, and Conventional Resources (PNL-3200). Richland, Washington: Pacific Northwest Laboratory, 1980.

Bloomster, C. H. and Schuller, C. R. "The Promise of Geothermal Energy Systems for Communities". Integrated Community Energy Systems Planning. Columbus, Ohio: Battelle, Columbus Laboratories, 1979.

Calm, lames M. Heat-Pump-Centered Integrated Community Energy Systems. Argonne, Illinois: Argonne National Laboratory, 1979.

Calm, James M. "Conservation Potential of Heat-Pump-Centered District Heating and Cooling", International Conference on Energy Use Management. Los Angeles, California, 1979 . 
Calm, James M., Roberts, John J., and Rabl, Veronika A. Thermal Transmission Integrated Community Energy Systems. Argonne, Illinois: Argonne National Laboratory, 1979.

Chappuis, P. "District Heating in Switzerland". Nuclear Technology (1977).

Davis, Allen A. Heat and Electrical Power Cogeneration Retrofitting Technique Costs and Benefits. Argonne, Illinois: Argonne National Laboratory, 1978.

Denesdi, Ludwig. "Modifying Turbines for District Water Heating". Power Engineering 83(8) (August 1979): 59-61.

Diamant, R. M. E. "District Heating with Combined Heat and Power Generation". District Heating 64(1) (July-August-September 1978): 30-40.

Diskant, William. "U.S.S.R. Trip Report". District Heating 64(3) (JanuaryFebruary-March 1979): 12-17.

"District Energy Suppliers in the United States and Canada". District Heating 62(3) (January-February-March 1977).

District Heating and Cooling Systems for Communities Through Power Plant Retrofit Distribution Network. Newark, New Jersey: Public Service Electric and Gas Company, 1979.

Donnelly, Peter F. and Sewell, Isaiah 0. "Regulation-Induced Uncertainties Seriously Impair Investment in District Heating Systems". District Heating 64(4) (April-May-June 1.979): 13-19.

Easton, Carroll W. "Conference on Energy Use Issues". District Heating 65(2) (October-November-December 1979): 9-11.

Fassbender, L. L. and Bloomster, C. H. "Economics of Geothermal Fluid Transport". Geothermal Energy 7(8) (August 1979): 28-35.

Fassbender, L. L. and Bloomster, C. H. Systems Analysis of Geothermal District Heating Costs (PNL-SA-7906). Richland, Washington: Pacific Northwest Laboratory, 1980.

Fazekas, Janos and Mamuzic, Mirko. "Measures to Ensure the Possibility of Future Heat Supply from the Kaiseraugst Nuclear Power Station". Nuclear Technology 38 (Apri1 1978): 75-82.

Fink, P. "District Heating Lines in Warsaw". Three R International 16(10) (October 1977): 602-605.

Gleason, Jack. "District Heating Saves Energy (In Europe)". Public Power 37(5) (September-0ctober 1979): 46-49.

Gradin, Rolf. "District Heating and Combined Heat and Power: Energy Policy Tools". Energy International 16(10) (October 1979): 35-36.

Hammer-Sorenson, F. L. "Actual Geothermal District Heating Developments in Germany and Denmark". Geo-Heat Utilization Center Quarterly Bulletin 4(4) (October 1979): 7-11. 
Haseler, E. "Warmth From Waste". Energy Digest 8(1) (February 1979): 36-40.

Hausz, Walter. "Seasonal Storage in District Heating". District Heating 63(1) (Ju1y-August-September 1977): 5-11.

Huber, H. D., McDonald, C. L., Bloomster, C. H., and Schulte, S. C. User Manual for GEOCITY: A Computer Model for Geothermal District Heating Cost Analys is (PNL-2742). Richland, Washington: Pacific Northwest Laboratory, 1978.

Jaderberg, L. "District Heating in Greater Stockholm". Nuclear Technology 38 (Apri1 1978): 50-53.

Jaehne, Herbert, Karnitz, Michael, Rubin, Alan, and Margen, Peter. "District Heating/Cogeneration Application Studies for the Minneapolis-St. Paul Area". District Heating 65(1) (July-August-September 1979): 26-40.

Karkheck, J., Powe 11, J., and Beardsworth, E. "Prospects for District Heating in the United States". Science 195 (March 1977): 948-955.

Karkheck, John and Tessmer, Raymond G. Public Data Sources and Modeling of District Heating in the United States. Upton, New York: Brookhaven National Laboratory, 1979.

Kilpinen, Unto. "Development of District Heating in Finland". District Heating 63(3) (January-February-March 1978): 22-26.

Kurz, Miklos G. "Long Range Planning of Large District Heating/Cooling Systems". District Heating 65(4) (2nd Quarter 1980): 6-21.

La Geothermie Chauffage de Logements. Paris, France: Electricite de France, 1976.

Lagowski, James P. "Overseas Trip Report". District Heating 63(3) (JanuaryFebruary-March 1978): 15-18.

Larsson, Kjell. "District Heating: Swedish Experience of an Energy Efficient Concept". District Heating 63(4) (April-May-June 1978): 14-32.

Lesse, R., Karkheck, J., Serry, H., and Tessmer, R. Data Base for District Heating Pipe System Design. Upton, New York: Brookhaven National Laboratory, 1979.

Lyon, R. B. and Sochaski, R. 0. Nuclear Power for District Heating. Pinawa, Manitoba, Canada: Whiteshell Nuclear Research Establishment, 1975.

Maag, William L. and Bollenbacher, Gary. Energy and Economic Analys is of Total Energy Systems for Residential and Commercial Buildings. Cleveland, Ohio: Lewis Research Center, 1974.

Marecki, Jacek. "Role of District Heating and Competition Problems with the Other Means of Heat Supply Against a Background of the World Fuel and Energy Situation". District Heating 62(1) (July-August-September 1976): 38-46.

Marecki, Jacek, Krajewski, Rudolf, and Renski, Andrzej. The Optimization Problems in a Large Nuclear Heat-and-Power Plant Connected to a Developing District Heating System. Poland: Technical IIniversity of Gdansk, 1977. 
Margen, Peter, Larsson, Kje11, Cronholm, Lars-Ake, and Marklund, Jan-Erik. Overall Feasibility and Economic Viability for a District Heating/New

Cogeneration System in Minneapolis-St. Paul. Oak Ridge, Tennessee: Oak Ridge Nationa 1 Laboratory, 1979.

Mauro, Robert L. "Is Cogeneration Feasible in the U.S.?" Public Power (January-February 1978): 24-27.

McCabe, John E. and Huxtable, Douglas D. "District Heating for Bellingham, Washington Using Waste Heat from an Aluminum Plant as the Energy Source". District Heating 65(3) (January-February-March 1980): 14-21.

McDonald, C. L. An Evaluation of the Potential for District Heating in the United States (BNWL-SA-6259). Richland, Washington: Pacific Northwest Laboratory, 1977.

McDonald, C. L., Bloomster, C. H., and Schulte, S. C. GEOCITY: A Computer Code for Calculating Costs of District Heating Using Geothermal Resources (BNWL2208). Richland, Washington: Pacific Northwest Laboratory, 1977.

McLoughlin, G. T. and Reinbergs, M. A New and Novel Form of District Heating Using Thermal Effluents from Electricity Generating Plants. Ottawa, Canada: Office of Energy Conservation, 1978.

Mejro, C. "Third International District Heating Conference, Warsaw, Poland". District Heating 62(2) (October-November-December 1976): 34-41.

Mikkelsen, Walther and Hammer-Sorensen, Flemming. District Heating by Cogeneration Through Retrofit and Decentralization. Chicago, Illinois: American Power Conference, 1980.

Moss, John. "Energy's Cinderella - Time for a Bal1?" New Scientist (May 24, 1979): 638-640.

Mustoe, F. Julian. "District Heating from Light Water Reactor Power Plants". Nuclear Engineering International (February 1979): 44-47.

0liker, I. Cogeneration District Heating Applications. New York, New York: The American Society of Mechanical Engineers, December 1978.

0liker, I. Problems of Piping Networks Supplied from Cogeneration Power Plants. New York, New York: The American Society of Mechanical Engineers, 1979.

0liker, I. and Muhlhauser, Helmut J. Technical and Economic Aspects of CoalFired District Heating Power Plants in U.S.A. Chicago, Illinois: American Power Conference, 1980.

0liker, I. and Philipp, J. "Technical and Economic Aspects of District Heating Systems Supplied from Cogeneration Power Plants". District Heating 64(1) (October-November-December 1978): 10-18.

Paterson, Andrew. "District Heating Review". District Heating 61(4) (Apri1May-June 1976): 34-36. 
Pearce, John, Karnitz, Michae1, Barnes, Michael, and Rubin, Alan. "Large-Scale District Heating and Cogeneration - Twin Cities Studies". Proceedings of the American Power Conference (40) (1978): 328-338.

Pourbaix, F. Transport of Heat in the Form of Hot Water. France: Electricite de France, $197 \overline{6}$.

Pourbaix, F. Urban Heating: Cost of the Heat Distribution. France: Electricite de France, 1976.

Prinz, W. "Flensburg, An Example of the Energetic Development of a District Heating System". Fernwarme Int. 39 (1977): 122-129.

Pyle, F. Bruce. "Recycle Energy System in Akron, Ohio". District Heating 65(1) (Ju1y-August-September 1979): 5-6.

Renshaw, Edward F. "Public Utilities and the Promotion of District Heating". Public Utilities Fortnightly 106(2) (July 17, 1980): 26-32.

Robb, Gordon A. "District Heating in Canada: Opportunities and Problems". District Heating 63(3) (January-February-March 1978): 33-37.

Santini, D. J., Davis, A. A., and Marder, S. M. Economic and Technical Analys is of Retrof it to Cogenerating District Energy Systems: North Central Cities. Argonne, Illinois: Argonne National Laboratory, 1979.

Scholten, Volker and Timm, Manfred. "Survey of Existing District Heating Systems". Nuclear Technology (38) (April 1978): 178-186.

Stone, W. A., Jenne, D. E., and Thorp, J. M. Climatography of the Hanford Area (BNWL-1605). Richland, Washington: Pacific Northwest Laboratory, 1972.

Strauss, Sheldon D. "District Heating Links with Cogeneration". Power 123(8) (August 1979): 72-75.

Sudurnes Hot Water System Primary Project. Reykjavik, Iceland: Fjarhitan, Ltd., March 1975.

Sundberg, R. E., Frost, E., Leas, R., and Hagstrom, K. Institutional Issues of a New District Heating/Cogeneration System - Ownership Options, Barriers, and Imp lementation Strategy. Oak Ridge, Tennessee: Oak Ridge National Laboratory, 1980.

Sundberg, Ronald E. and Nyman, Hans 0 . Methods and Cost Estimates for Converting Existing Buildings to Hot Water District Heating. Oak Ridge, Tennessee: Oak Ridge National Laboratory, 1979.

Winkens, Hans-Peter. "Germany Looks Toward Nuclear District Heating". District Heating 61(2) (October-November-December 1975): 22-26.

Yeoman, John C. A Net Energy Analys is of a Cogeneration-District Heating System and Two Conventional Alternatives. Oak Ridge, Tennessee: Oak Ridge Nationa 7 Laboratory, 1979. 
PNL -3719

UC -12

\section{DISTRIBUTION}

No. of

Copies

\section{OFFSITE}

A. A. Churm

DOE Patent Division

9800 S. Cass Avenue

Argonne, IL 60439

W. F. Savage

Department of Energy

Mail Stop B-107

Germantown, MD 20545

Jack Stader

Department of Energy

Nuclear Reactor Program Office

Washington, D.C. 20545

Isaiah Sewe 11

Department of Energy

Conservation and Renewable

Resources

Office of Buildings and

Community Systems

Forrestal Building

Washington, D.C. 20585

27 DOE Technical Information

Center

Sharon Engstrom

Washington Public Power

Supply System

P. 0. Box 968

Richland, WA 99352

Pat Fox

Bonneville Power

Administration

1002 N.E. Holladay

Portland, OR 97208
No. of

Copies
Chris Kondrat

Bonnevile Power

Administration

1002 N.E. Holladay

Portland, OR 97208

Gary Mabley

City of Richland

Planning Department

505 Swift Boulevard

Richland, WA 99352

Craig McDonald

Math Sciences Northwest

P. 0. Box 1887

Bellevue, WA 98009

Duane Renberger

Washington Public Power

Supply System

P. 0. Box 968

Richland, WA 99352

Ron Robinson

Tri-City Nuclear

Industrial Council

707 Jadwin Avenue

Richland, WA 99352

Peter K. Shen

Washington Public Power

Supply System

P. 0. Box 968

Richland, WA 99352

Gordon W. Jacobsen

Northwest Energy Services

Company

Box 1090

Kirkland, WA 98033 
PNL -3719

UC -12

\section{DISTR IBUT ION}

(Continued)

No. of

Copies

\section{OFFS ITE}

Neil Harpster

Lamb-Weston

2013 Saint

Richland, WA 99352

John Huckabee

Electric Power Research

Institute

$3412 \mathrm{Hillview} \mathrm{Avenue}$

Palo Alto, CA 94304

Neal Shulman, City Manager

City of Richland

505 Swift Boulevard

Richland, WA 99352

Edward W. Sienkiewicz, Jr. Bonneville Power

Administration

1.002 N.E. Holladay

Portland, OR 97208

Randa 11 L. Snipes

Tennessee Valley Authority

1060 Chestnut Street

Tower II

Chattanooga, TN 37401

Keith Sedore

City of Richland

Energy Services Division

505 Swift Boulevard

Richland, WA 99352
No. of

Copies
John Maulbetsch

Electric Power Research

Institute

3412 Hillview Avenue

Palo Alto, CA 94304

Orin Zimmerman

Electric Power Research

Institute

3412 Hillview Avenue

Palo Alto, CA 94304

Harry L. Brunsdon

Washington State Senate

Energy \& Utilities Committee

102 Institutions Building

01ympia, WA 98504

Pete P. Ramatowsk $i$

Bonneville Power

Administration

1002 N.E. Holladay

Portland, OR 97208

Robert $D$. Leedy

City of Richland

Planning Department

505 Swift Boulevard

Richland, WA 99352

Gordon Reistad

Department of Mechanical

Engineering

Oregon State University

Corvallis, OR 97331 
PNL -3719

UC-12

$\frac{\text { DISTR IBUT ION }}{(\text { Cont inued })}$

No. of

Copies

ONSITE

DOE Richland Operations Office

Len Perkins

H. E. Ransom

Jim Anderson

Rich Holten

Ken Bracken

Hanford Engineering Development

Laboratory

Ken Hayden

73 Pacific Northwest Laboratory

F. W. Albaugh

C. H. Bloomster (27)

N. G. Carter

D. E. Deonigi

L. L. Fassbender (27)

H. Harty

H. D. Huber

L. V. Kimme 1

R. W. Reil1y

L. C. Schmid

L. D. Williams

Economics Library (3)

Technical Information Files (5)

Publishing Coordination (2) 


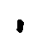

-

. 